\title{
Epigenetic Biomarkers of Renal Cell Carcinoma for Liquid Biopsy Tests
}

\author{
Raimonda Kubiliute ${ }^{1,2}$ and Sonata Jarmalaite 1,2,* $^{\text {. }}$ \\ 1 Life Sciences Center, Institute of Biosciences, Vilnius University, Saulètekio Av. 7, 10257 Vilnius, Lithuania; \\ raimonda.kubiliute@gmc.vu.lt \\ 2 National Cancer Institute, 08660 Vilnius, Lithuania \\ * Correspondence: sonata.jarmalaite@nvi.lt
}

Citation: Kubiliute, R.; Jarmalaite, S. Epigenetic Biomarkers of Renal Cell Carcinoma for Liquid Biopsy Tests. Int. J. Mol. Sci. 2021, 22, 8846. https://doi.org/10.3390/ ijms22168846

Academic Editor: Luca Agnelli

Received: 20 July 2021

Accepted: 13 August 2021

Published: 17 August 2021

Publisher's Note: MDPI stays neutral with regard to jurisdictional claims in published maps and institutional affiliations.

Copyright: (C) 2021 by the authors Licensee MDPI, Basel, Switzerland. This article is an open access article distributed under the terms and conditions of the Creative Commons Attribution (CC BY) license (https:// creativecommons.org/licenses/by/ $4.0 /)$.
Abstract: Renal cell carcinomas (RCC) account for 2-3\% of the global cancer burden and are characterized by the highest mortality rate among all genitourinary cancers. However, excluding conventional imagining approaches, there are no reliable diagnostic and prognostic tools available for clinical use at present. Liquid biopsies, such as urine, serum, and plasma, contain a significant amount of tumorderived nucleic acids, which may serve as non-invasive biomarkers that are particularly useful for early cancer detection, follow-up, and personalization of treatment. Changes in epigenetic phenomena, such as DNA methylation level, expression of microRNAs (miRNAs), and long noncoding RNAs (lncRNAs), are observed early during cancer development and are easily detectable in biofluids when morphological changes are still undetermined by conventional diagnostic tools. Here, we reviewed recent advances made in the development of liquid biopsy-derived DNA methylation-, miRNAs- and lncRNAs-based biomarkers for RCC, with an emphasis on the performance characteristics. In the last two decades, a mass of circulating epigenetic biomarkers of RCC were suggested, however, most of the studies done thus far analyzed biomarkers selected from the literature, used relatively miniature, local, and heterogeneous cohorts, and suffered from a lack of sufficient validations. In summary, for improved translation into the clinical setting, there is considerable demand for the validation of the existing pool of RCC biomarkers and the discovery of novel ones with better performance and clinical utility.

Keywords: renal cell carcinoma; epigenetic alterations; DNA methylation; miRNAs; lncRNAs; non-invasive detection; liquid biopsy

\section{Introduction}

Based on its incidence in both sexes, kidney (or renal) cancer takes fourteenth place worldwide and is among the top ten most common cancers in males (according to IARC, https:/ /gco.iarc.fr/, accessed on 7 July 2021). Renal cell carcinoma (RCC), originating from the epithelium of the nephron tubules, is the most common type of kidney cancer, accounting for $90 \%$ of all cases, and is the most lethal cancer of the urinary system [1,2]. The three major subtypes of RCC are clear cell RCC (ccRCC), representing the most common and aggressive form (70-80\%), papillary RCC (pRCC), accounting for 10-15\%, and chromophobe RCC (chRCC), accounting for 5\% of RCC; meanwhile, the remaining subtypes are very rare [3]. While the majority of patients will present with localized disease, $25-40 \%$ of those treated with curative intent will develop distant disease and $20-25 \%$ of patients will present with metastatic disease at diagnosis [4], which is, presumably, the source of the significant health burden of RCC. This is attributed to the characteristic lack of symptoms associated with primary RCC and, currently, the majority of patients are diagnosed incidentally due to the extensive use of radiology imaging for the investigation of various non-specific symptoms [5,6]. The possibility for diagnosing disease using liquid biopsy-based molecular biomarker tests, along with imaging, could not only enhance early 
diagnosis, but also facilitate patients' follow-up and differentiation into low and high-risk progression groups.

The potential sources for disease biomarkers include tumor tissue (biopsy) and bodily fluids, such as urine, blood serum, or plasma. Recent studies analyzing multiregional and sequential tumor samples by genome-wide mutation analyses [7-9] suggested a high heterogeneity of ccRCC tumors, which is overlooked in the single biopsy studies, and even $73-75 \%$ of driver alterations were found to be subclonal [10]. Biopsies are less appropriate for patients' follow-up due to hazardous and painful procedures. Thus, to date, "liquid biopsy" is emerging as a revolutionary tool in cancer care with some important advantages over tissue biopsy. First of all, intratumor heterogeneity may be captured better in body fluids, reflecting a wider spectrum of (epi)genetic alterations from various tumor foci and even micrometastatic spots. Most importantly, concerning its non-invasive (urine) or minimally invasive (blood) nature, liquid biopsies can be obtained frequently and, due to the ease of availability, repeatability, and comparability, allow for the detection of cancer at an early stage or the following of the real-time state of the malignant transformation and disease progression.

The recent study by Mitchell et al. [7] revealed that clonal expansion of ccRCC tumors is dilatory and a long period of time (up to 50 years) is required from the initial genetic alteration to clinical manifestation of a tumor. While hardly any histological change is evident in the corresponding histologically normal renal tissue of patients with renal tumors, epigenetic alterations will have already accumulated in such non-cancerous renal tissues [11], suggesting their suitability for early diagnosis of the disease. Epigenetic phenomena, particularly DNA methylation, microRNAs (miRNAs), and long noncoding RNAs (lncRNAs), can modulate gene expression and such changes are frequent and related to various clinical subgroups of RCC [12-14]. In addition, in comparison with genetic alterations, epigenetic changes are more pronounced and frequent in all RCC subtypes [15]. Moreover, epigenetic marks can be easily detected in the body fluids, such as urine or peripheral blood samples, by conventional and inexpensive qualitative or quantitative PCR methods. Thus, epigenetic alterations may serve as non-invasive biomarkers that could provide clinicians with rapid, objective, and accurate tools for the detection of and follow-up on renal tumors.

Despite their potential, no diagnostic and prognostic non-invasively detectable RCCspecific epigenetic biomarkers have reached the clinical setting yet; meanwhile, DNA methylation-based tests for other urological cancers (prostate and bladder) have been commercially available for a long period of time [16]. Navigation toward clinical utility is challenging and requires representative, large, and preferably multiregional patient series as well as sufficient validations. Here, we provide an overview of currently described potential DNA methylation-, miRNA-, and lncRNA-based urine and blood circulating biomarkers for kidney cancer detection and/or prognosis without detailing the technical issues thoroughly described elsewhere $[17,18]$. To provide a summary of the present knowledge, a systemic search using PubMed was performed (updated 7 July 2021). The literature search encompassed the terms "DNA methylation AND renal cell carcinoma AND urine/serum/plasma", "miRNA AND renal cell carcinoma AND urine/serum/plasma" and "IncRNA AND renal cell carcinoma AND urine/serum/plasma". In addition, references of the relevant publications were reviewed to include additional eligible research. It is worth mentioning that only manuscripts describing adult RCC cases were discussed, while investigations related to genetic syndromes, such as Wilms tumors, were excluded.

\section{Biofluid DNA Methylation as the Biomarkers for Renal Cell Carcinoma}

DNA methylation in mammalian cells is characterized by the addition of a methyl group (-CH3) at the carbon-5 position of cytosine residues in the context of $\mathrm{CpG}$ dinucleotides through the action of DNA methyltransferase (DNMTs) enzymes, forming 5 -methylcytosine $(5 \mathrm{mC})$. It is the most widely studied epigenetic mechanism, responsible for various biological processes including the normal development of mammals, differen- 
tiation, and regulation of gene expression [19]. Promoter CpGs in normal cells generally remain unmethylated (hypomethylated) and are associated with active gene expression during differentiation. However, hypermethylation of the promoter CpGs is a common event in various cancer types, including kidney cancer, and is often associated with the silencing of tumor suppressor genes and downstream signaling pathways $[19,20]$. Alterations in DNA methylation occur early during cancer development and, in the case of ccRCC, are observable even in the precancerous stage [11,21] with increasing promoter hypermethylation frequencies in higher stage and grade tumors [22]. Aberrant DNA methylation is easily detectable in body fluids by conventional PCR-based methods. Considering the relatively infrequent number of somatic mutations and slow progress of clonal expansion until cancer diagnosis $[7,23]$, DNA methylation could be precious clinical cancer biomarkers for the early diagnosis and prognosis of kidney cancer.

Despite the high potential of DNA methylation as the disease biomarker, only 12 studies shed light on efforts to analyze DNA methylation in liquid biopsy specimens as noninvasive biomarkers for RCC [24-35] (Table 1), encompassing 25 individual genes. Four (33\%) of 12 studies discussed used urine as the source of methylated DNA, six studies $(50 \%)$ reported on serum or plasma, and two (17\%) described both urine and serum/plasma. Most of the biomarkers studied were classic tumor suppressor genes known to be involved or methylated in several human cancers [36], and only one study based their biomarker selection on gene expression microarrays data performed on renal cancer cell lines [27]. In addition, one study used high-throughput sequencing to detect RCC [35]. For the validation, the ruling methods were the bisulfite conversion-based MSP or qMSP with rare exceptions (Table 1). Only two studies by Outeiro-Pinho et al. [34] and Nuzzo et al. [35] performed internal validation with training and test sample sets, while others missed this step. In addition, $58 \%$ of the studies included $\leq 50$ RCC patients and only two studies $[32,34]$ used a homogenous study cohort composed of patients with ccRCC, while others involved heterogeneous groups of patients with various types of renal tumors $[24,27-29,31,33,35]$ and, in some cases, the particular subtype was not specified $[25,26,30]$.

Most studies compared circulating methylated DNA data with matched (or not) tissue samples [24-27,30,33,34], while no identical DNA methylation patterns between primary tumor and liquid biopsies were identified, and, as a rule, lower methylation frequencies or intensities in the body fluids were detected. The diagnostic sensitivity of various individual biomarkers varied from $6 \%$ to $83 \%$, while the specificity was generally high and reached $>90 \%$ for most of the biomarkers (Table 1). Interestingly, Hoque et al. [25] found higher methylation frequencies of APC, ARF, GSTP1, P16, RARB2, RASSF1A, and TIMP3 in the urine samples when compared to the matched serum samples, while specificities were almost the same. However, too few samples $(n=17)$ were compared to conclude that urine was a more sensitive tool for cancer diagnosis. 
Table 1. Studies concerning DNA methylation in biofluids as a potential biomarker of renal cell carcinoma.

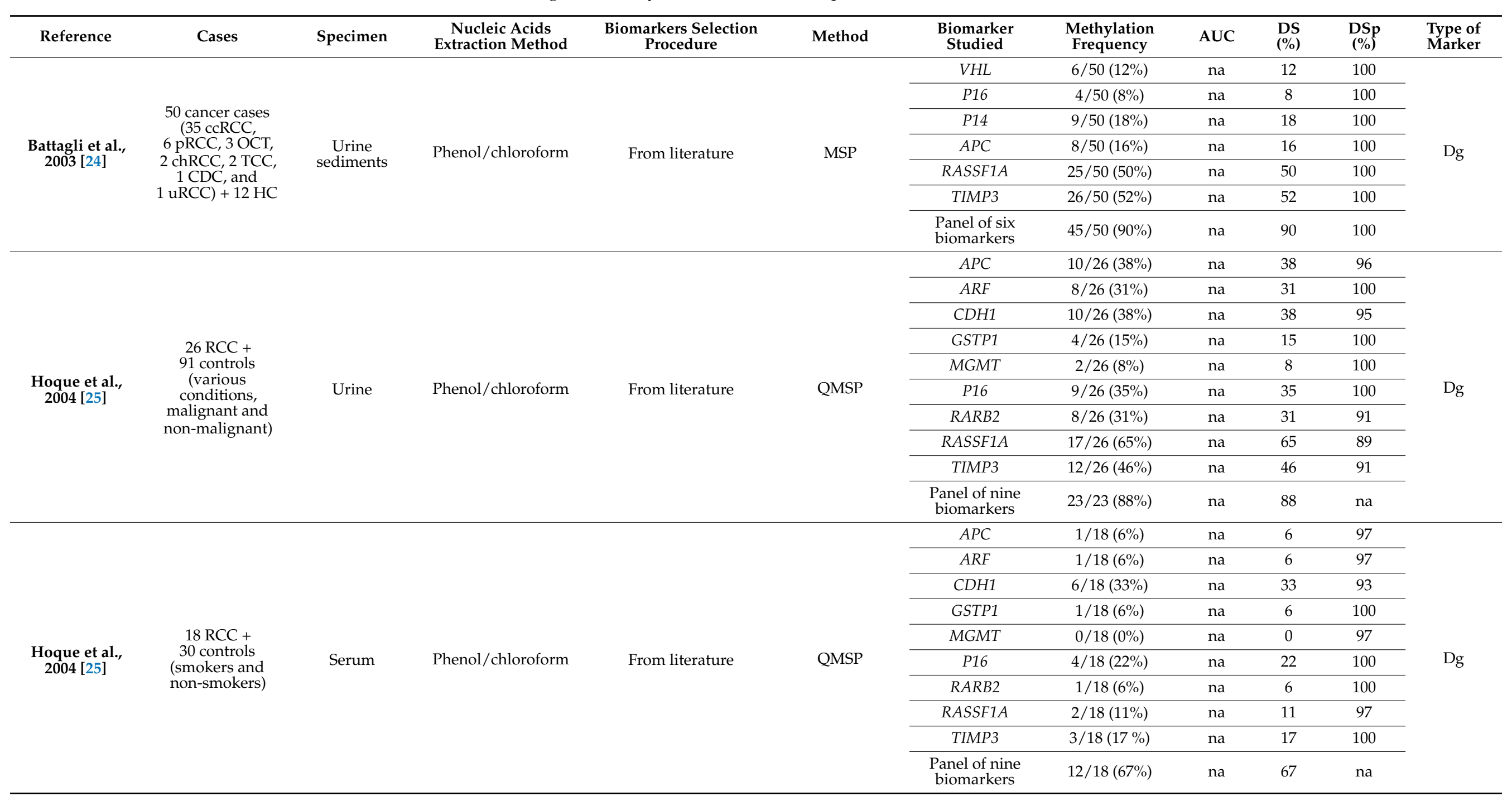


Table 1. Cont.

\begin{tabular}{|c|c|c|c|c|c|c|c|c|c|c|c|}
\hline Reference & Cases & Specimen & $\begin{array}{c}\text { Nucleic Acids } \\
\text { Extraction Method }\end{array}$ & $\begin{array}{c}\text { Biomarkers Selection } \\
\text { Procedure }\end{array}$ & Method & $\begin{array}{l}\text { Biomarker } \\
\text { Studied }\end{array}$ & $\begin{array}{l}\text { Methylation } \\
\text { Frequency }\end{array}$ & AUC & $\begin{array}{l}\text { DS } \\
(\%)\end{array}$ & $\begin{array}{l}\text { DSp } \\
(\%)\end{array}$ & $\begin{array}{l}\text { Type of } \\
\text { Marker }\end{array}$ \\
\hline \multirow{6}{*}{$\begin{array}{l}\text { Urakami et al., } \\
2006[26]\end{array}$} & \multirow{6}{*}{$33 \mathrm{RCC}+20 \mathrm{HC}$} & \multirow{6}{*}{ Serum } & \multirow{6}{*}{$\begin{array}{c}\text { QIAmp DNA Mini } \\
\text { Blood } \\
\text { kit (Qiagen) }\end{array}$} & \multirow{6}{*}{ From literature } & \multirow{6}{*}{ MSP } & SFRP1 & $9 / 33(27.3 \%)$ & na & 27.3 & 100 & \multirow{6}{*}{$\mathrm{Dg}$} \\
\hline & & & & & & SFRP2 & $16 / 33(48.5 \%)$ & na & 48.5 & 100 & \\
\hline & & & & & & SFRP4 & $8 / 33(24.2 \%)$ & na & 24.2 & 100 & \\
\hline & & & & & & SFRP5 & $15 / 33(45.5 \%)$ & na & 45.5 & 100 & \\
\hline & & & & & & DKK3 & $9 / 33(27.3 \%)$ & na & 27.3 & 100 & \\
\hline & & & & & & WIF1 & $9 / 33(27.3 \%)$ & na & 27.3 & 100 & \\
\hline \multirow{2}{*}{$\begin{array}{l}\text { Costa et al., } \\
2011[27]^{*}\end{array}$} & \multirow{2}{*}{$\begin{array}{c}50 \text { RCC (34 } \\
\text { cCRCC, } 7 \text { pRCC, } \\
4 \text { chRCC, and } \\
5 \text { OCT })+48 \text { HC }\end{array}$} & \multirow{2}{*}{$\begin{array}{l}\text { Urine } \\
\text { sediments }\end{array}$} & \multirow{2}{*}{ Phenol/chloroform } & \multirow{2}{*}{$\begin{array}{l}\text { Gene expression } \\
\text { microarrays (Applied } \\
\text { Biosystems) }\end{array}$} & \multirow{2}{*}{ QMSP } & PCDH17 & $10 / 50(50 \%)$ & na & 20 & 100 & \multirow{2}{*}{$\mathrm{Dg}$} \\
\hline & & & & & & $\begin{array}{l}\text { TCF21 or } \\
\text { PCDH17 }\end{array}$ & $16 / 50(32 \%)$ & 0.66 & 32 & 100 & \\
\hline \multirow{4}{*}{$\begin{array}{l}\text { de Martino } \\
\text { et al., } 2011 \text { [28] }\end{array}$} & \multirow{4}{*}{$\begin{array}{c}157 \text { (112 ccRCC, } \\
31 \text { pRCC, and } \\
14 \text { chRCC }+ \\
43 \text { BRT }\end{array}$} & \multirow{4}{*}{ Serum } & \multirow{4}{*}{$\begin{array}{l}\text { QIAamp Ultrasens } \\
\text { Virus Kit (Qiagen) }\end{array}$} & \multirow{4}{*}{ From literature } & \multirow{4}{*}{$\begin{array}{l}\text { Restriction } \\
\text { endonuclease } \\
\text { qPCR }\end{array}$} & RASSF1A & $75 / 200(37.5 \%)$ & 0.69 & 45.9 & 93.0 & \multirow{4}{*}{$\mathrm{Dg}$} \\
\hline & & & & & & VHL & $83 / 200(41.5 \%)$ & 0.71 & 50.3 & 90.7 & \\
\hline & & & & & & PTGS2 & $75 / 200(37.5 \%)$ & 0.52 & 38.2 & 65.1 & \\
\hline & & & & & & $P 16$ & $92 / 200(46 \%)$ & 0.51 & 46.5 & 55.8 & \\
\hline \multirow{13}{*}{$\begin{array}{l}\text { Hauser et al., } \\
2013[29]\end{array}$} & \multirow{13}{*}{$\begin{array}{c}35 \text { RCC ( } 29 \\
\text { ccRCC, } 4 \text { pRCC, } \\
\text { and } 2 \text { chRCC })+ \\
54 \text { HC }\end{array}$} & \multirow{13}{*}{ Serum } & \multirow{13}{*}{$\begin{array}{c}\text { ChargeSwitch gDNA } \\
\text { Kit } \\
\text { (Invitrogen) }\end{array}$} & \multirow{13}{*}{ From literature } & \multirow{13}{*}{$\begin{array}{l}\text { Restriction } \\
\text { endonuclease } \\
\text { qPCR }\end{array}$} & $A P C$ & $19 / 35(54.3 \%)$ & 0.72 & 54.3 & 90.7 & \multirow{13}{*}{$\mathrm{Dg}$} \\
\hline & & & & & & P14 & $5 / 35(14.3 \%)$ & 0.57 & 14.3 & 100 & \\
\hline & & & & & & P16 & $9 / 35(25.7 \%)$ & na & 25.7 & 83.3 & \\
\hline & & & & & & PTGS2 & $8 / 35(22.9 \%)$ & 0.59 & 22.9 & 96.3 & \\
\hline & & & & & & $R A R B$ & $14 / 35(40 \%)$ & 0.61 & 40.0 & 85.2 & \\
\hline & & & & & & RASSF1A & $8 / 35(22.9 \%)$ & 0.60 & 22.9 & 98.2 & \\
\hline & & & & & & TIMP3 & $20 / 35(57.1 \%)$ & na & 57.1 & 61.1 & \\
\hline & & & & & & $\begin{array}{l}\text { Panel of eight } \\
\text { biomarkers }\end{array}$ & $30 / 35(85.7 \%)$ & na & 85.7 & na & \\
\hline & & & & & & APC or GSTP1 & na & 0.73 & 57.1 & 88.9 & \\
\hline & & & & & & APC or PTGS2 & na & 0.74 & 60.0 & 87.0 & \\
\hline & & & & & & APC or PTGS2 & na & 0.74 & 60.0 & 87.0 & \\
\hline & & & & & & $A P C$ or $R A R B$ & na & 0.76 & 74.3 & 77.8 & \\
\hline & & & & & & $\begin{array}{c}\text { PTGS2 or } \\
\text { GSTP1 }\end{array}$ & na & 0.75 & 62.9 & 87.0 & \\
\hline
\end{tabular}


Table 1. Cont.

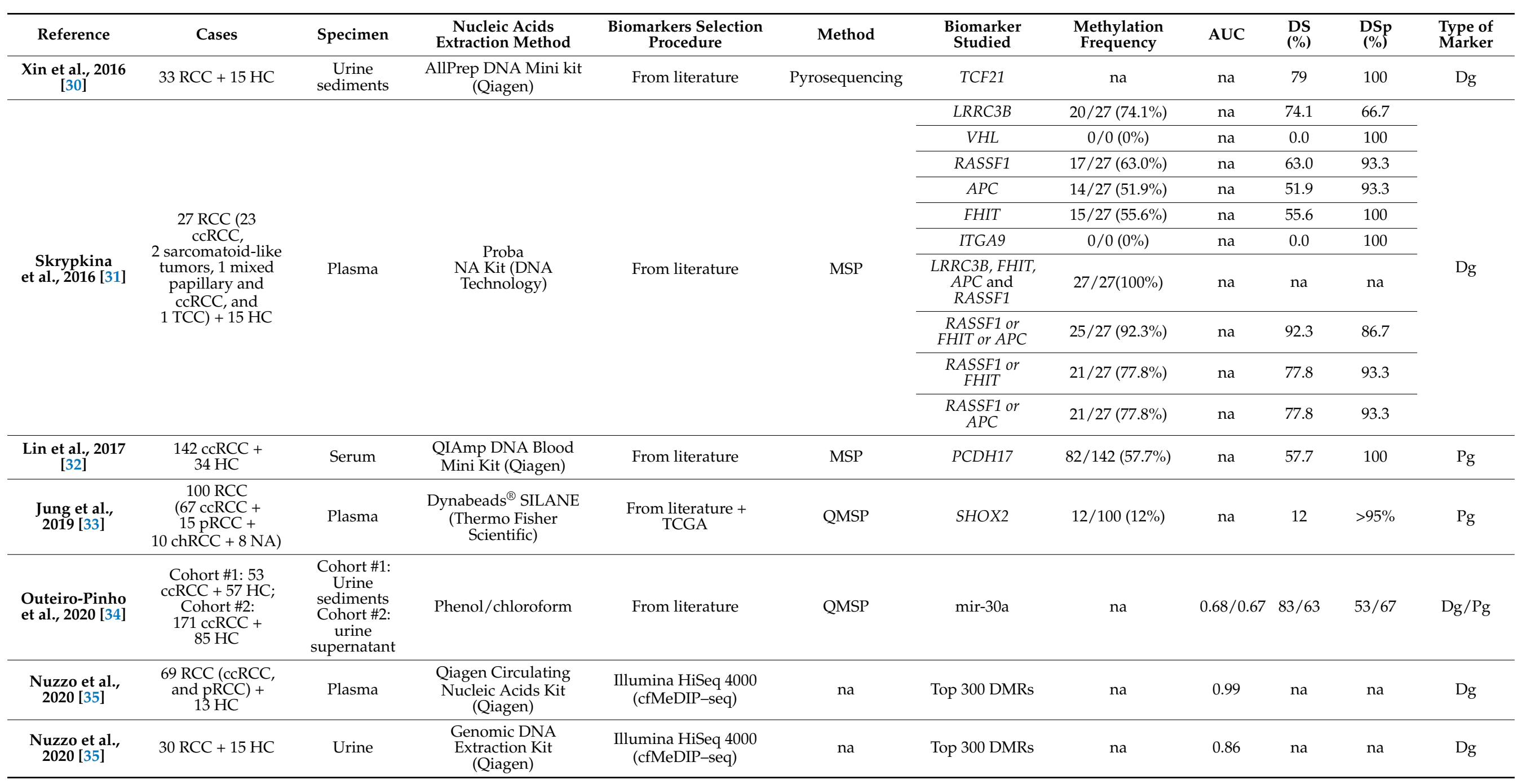

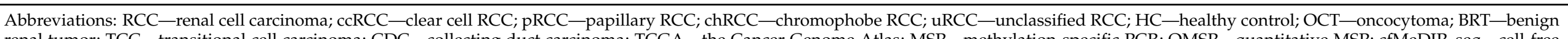

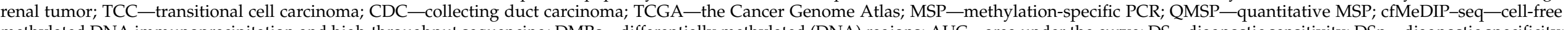

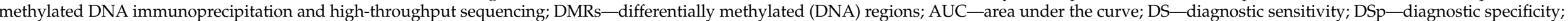
$\mathrm{Dg}$-diagnostic; $\mathrm{Pg}$ - prognostic; na—not applicable/available. * The provided AUC, S, and Sp values indicate the prognostic performance for CSS. 
In five studies [24,25,27,29,31], biomarker combinations were evaluated with the best performing combination of six biomarkers, namely VHL, P16, P14, APC, RASSF1A, and TIMP3, achieving $90 \%$ sensitivity and $100 \%$ specificity in the urine samples [24]. Skrypkina et al. [31] found a similar sensitivity (92\%) for the panel of only three genes, RASSF1A, FHIT, and APC, in the plasma samples; however, the specificity was lower (87\%).

The most innovative research on non-invasive RCC detection was performed by Nuzzo et al. [35], who used cell-free methylated DNA immunoprecipitation and high throughput sequencing (cf-MeDIP-seq) for highly sensitive detection of early-stage tumors. The investigators performed cf-MeDIP-seq on plasma cell-free DNA samples and identified differentially methylated regions (DMRs) between patients and control groups to build a classifier. The top 300 DMRs were selected, enabling accurate detection of all stages of RCC with an AUC $=0.99$ and an AUC $=0.86$ in the plasma and urine samples, respectively. Moreover, the created classifier strongly distinguished RCC from urothelial bladder cancer in the plasma samples with an AUC $=0.98$. However, due to complexity, the translational potential of such a classifier to clinical practice is currently limited.

Seven studies in total revealed significant associations of circulating DNA methylation biomarkers with clinical-pathological variables [26,28-30,32-34]. Urakami et al. [26] found a higher methylation frequency of all genes in combination (SFRP1, SFRP2, SFRP3, SFRP4, SFRP5, DKK3, and WIF1) in higher grade and higher stage RCC. Not surprisingly, de Martino et al. [28] found higher VHL methylation in patients with ccRCC compared to other subtypes, but no associations were observed among other clinical-pathological variables. Houser et al. [29] described a higher methylation level of APC in patients with pT3 tumors when compared to pT1 stage RCC. Xin et al. [30] reported a positive association of TCF21 methylation level, tumor stage, and Fuhrman grade as well as a clinical-stage. Lin et al. [32] correlated PCDH17 methylation with higher tumor stage, grade, and lymph node metastasis. Jung et al. [33] found a positive correlation between SHOX2 methylation and $\mathrm{T}, \mathrm{N}$, and $\mathrm{M}$ categories, histopathological grade, and lymphovascular invasion. Finally, Outeiro-Pinho et al. [34] observed higher urinary levels of methylated miRNA gene mir30a in patients with an advanced pathological stage and those that recurred or developed metastasis during follow-up.

The independent prognostic value of circulating methylated DNA biomarkers was reported in only three studies discussed [32-34]. Lin et al. [32] defined PCDH17 methylation as an independent factor for worse progression-free survival (PFS) and overall survival (OS) of patients with ccRCC; the adjusted (by sex, age, stage, grade, and lymph node metastasis) HRs were 4.0 and 3.9, respectively. Jung et al. [33] showed a significantly higher risk of death for patients with an increased blood plasma level of methylated SHOX2 with an HR of 1.5, and the association remained significant even after adjustment to the tumor stage. Outeiro-Pinho et al. [34] described an association between higher levels of methylated urinary mir-30a and shorter metastasis-free survival and disease-specific survival (DSS); however, in the multivariable analysis, methylated mir-30a depicted an independent prognostic value for only DSS. No such associations were found, however, in the independent study cohort, which perfectly reflects the necessity of validating such results.

In summary, although 25 individual DNA methylation biomarkers for non-invasive detection and/or follow-up of patients with renal cancer were published, only 12 of them were investigated in an independent study or population. Among all biomarkers, only a few individual markers (TCF21, LRRC3B, and mir-30a) and multimarker panels (investigated by Battagi et al. [24], Hoque et al. [25], Urakami et al. [26], Houser et al. [29], and Skrypkina et al. [31]) showed sensitivities $>70 \%$, thereby making them potentially promising diagnostic biomarkers. However, these markers and panels either were studied in small heterogeneous populations [24-26,29-31] or the discriminating ability was plumped to a clinically insignificant level after validation in the larger cohort [34]. In addition, the majority of studies examined well-known tumor suppressor genes also known to be methylated in several cancer types, thus non-specific for RCC. In the future, next-generation 
sequencing-based hunting of biomarkers in biofluids seems to be the most promising tool for biomarker discovery.

\section{Biofluid miRNAs as Biomarkers for Renal Cell Carcinoma}

MicroRNAs (miRNAs) are a group of small, non-coding RNAs, 18-25 nucleotides in length, which regulate target gene expression by binding to the complementary $3^{\prime}$ UTR of mRNA and inhibiting its translation to the protein or promoting degradation $[37,38]$. Accumulating pieces of evidence suggest the involvement of miRNAs in many processes related to cancer development and progression, including angiogenesis [39,40], cell proliferation [41,42], apoptosis [43,44], metastasis [45,46], invasion, as well as drug and radiation resistance [46-48]. The aberrant expression of miRNAs in renal cell carcinoma was observed by several independent studies, and evidence showed their involvement in RCC pathogenesis $[49,50]$. Moreover, miRNAs can be detected in various sources of biofluids, including serum, plasma, saliva, and urine [51]. The circulating miRNAs are protected from the endogenous RNase activity by binding with some proteins (e.g., Argonaute 2 protein) and lipoproteins $[52,53]$ or due to the protection by secretory particles, such as apoptotic bodies, microvesicles, and exosomes $[54,55]$, resulting in the remarkable stability of these molecules in biofluids. Indeed, circulating miRNAs are stable against degradation by RNase, $\mathrm{pH}$ changes, and freezing/thawing [56], thus may serve as non-invasive biomarkers. The profile of miRNAs expression is similar in men and women as well as in individuals characterized by different ages [57], which is possibly the main advantage miRNAs, as biomarkers, has over DNA methylation.

While compared to DNA methylation analysis, considerably more studies (43 discussed here), were completed concerning the topic of miRNAs as non-invasive biomarkers for RCC, including seven multicenter studies [58-100] (Table 2), encompassing $>70$ unique miRNAs. The vast majority ( $77 \%$ ) of the studies (33 in total) used blood as the source of RNA, and serum was more common than plasma (used in 21 and 12 studies, respectively) despite the observation that the coagulation process may affect the spectrum of extracellular miRNAs in the blood, namely the platelet-derived ones [101]. Surprisingly, only 10 studies $(23 \%)$ using urine samples for miRNA analysis in patients with RCC were reported. Seven studies specifically focused on the exosome- or microvesicles-derived miRNAs $[72,74,78,88,89,96,99]$. More than half of the studies based their biomarkers selection procedure on literature search, focusing on miRNA biomarkers studied in the kidney or in other cancer types. Biomarker selection in the remaining studies, on the other hand, was performed by the mining of specific databases (e.g., TCGA or Gene Expression Omnibus) or after initial miRNA screening by TaqMan Low-Density Arrays (TLDA), miRNA expression microarrays, and even the sequencing of liquid biopsy specimens $[78,85,89,90]$ to select RCC-specific candidate biomarkers. In addition, most of the studies (89\%) lacked an internal validation with training and validation sets or lacked the performance of internal validation approaches. Moreover, relatively few studies included $>100$ RCC patient samples in the validation step, and almost a third of studies investigated $<50$ of samples only.

Most of the studies (92\%) primarily focused on the diagnostic objective of discrimination between patients with RCC and healthy or cancer-free controls. The study cohorts consisted either of patients with only clear cell RCC, or a heterogeneous group of patients, including papillary, chromophobe, or sarcomatoid RCC, as well as benign renal tumors (e.g., oncocytomas and angiomyolipomas), and only one study exclusively investigated serum samples obtained solely from pRCC patients [95]. Some studies compared circulating miRNA data with matched RCC and normal tissue [58-60,63-66,71,76,79,82,84,87,88,91,94], but the observed expression changes were not always concordant. For example, Zhao et al. [91] found the opposite regulation of miR-625-3p in the ccRCC tissue and serum samples, which was explained by the selective release of miRNAs from tumor cells. 
Table 2. Studies concerning microRNAs in biofluids as potential biomarkers of renal cell carcinoma.

\begin{tabular}{|c|c|c|c|c|c|c|c|c|c|c|}
\hline Reference & Sample Size & Sample & RNA Isolation & Biomarker Selection & Method (Reference) & $\begin{array}{c}\text { Biomarker Studied, } \\
\text { Regulation }\end{array}$ & AUC & $\begin{array}{l}\text { DS } \\
(\%)\end{array}$ & $\begin{array}{l}\text { DSp } \\
(\%)\end{array}$ & $\begin{array}{l}\text { Type of } \\
\text { Marker }\end{array}$ \\
\hline $\begin{array}{l}\text { Wulfken et al., } \\
2011[58]^{* *}\end{array}$ & $\begin{array}{c}\text { Screening phase: } 6 \text { ccRCC }+6 \mathrm{HC} \text {; Validation } \\
\text { phase\#1: } 33 \text { ccRCC }+30 \mathrm{HC} ; \\
\text { Validation phase\#2: } 84 \mathrm{RCC}(69 \mathrm{ccRCC}, 10 \mathrm{pRCC}, \\
3 \text { chRCC, and } 2 \text { sRCCC) + } 106 \text { controls }(93 \mathrm{HC}, 3 \\
\text { AML, and } 10 \mathrm{OCT})\end{array}$ & Serum & $\begin{array}{l}\text { mirVana PARIS Kit } \\
\text { (Ambion) }\end{array}$ & $\begin{array}{l}\text { TLDA (tissue and } \\
\text { serum) }\end{array}$ & $\begin{array}{l}\text { qRT-PCR (TaqMan) } \\
\quad(\text { miR-39) }\end{array}$ & $\operatorname{miR}-1233 \uparrow$ & 0.59 & 77.4 & 37.6 & $\mathrm{Dg}$ \\
\hline $\begin{array}{l}\text { Zhai et al., } \\
2012[59]\end{array}$ & $10 \mathrm{RCC}+10 \mathrm{HC}$ & Plasma & TRIzol (Invitrogen) & $\begin{array}{l}\text { Sequencing (on } \\
\text { tissue-derived RNA) }\end{array}$ & $\begin{array}{l}\text { qRT-PCR (Qiagen) } \\
\text { (RNU6) }\end{array}$ & miR-508-3p $\downarrow$ & na & na & na & na \\
\hline $\begin{array}{l}\text { Brandenstein } \\
\text { et al., 2012 [60] }\end{array}$ & $\begin{array}{c}10 \mathrm{RCC}+35 \text { controls }(5 \mathrm{OCT}, 1 \mathrm{AML}, 9 \mathrm{RCC} \\
\text { regressive, and } 15 \text { various inflammation or } \\
\text { malignancies) }\end{array}$ & Whole urine & miRNeasy kit (Qiagen) & From literature & $\begin{array}{l}\text { qRT-PCR (TaqMan) }(5 \mathrm{~S} \\
\text { rRNA) }\end{array}$ & $\operatorname{miR}-15 \mathrm{a} \uparrow$ & na & na & na & na \\
\hline $\begin{array}{l}\text { Redova et al., } \\
\quad 2012[61]\end{array}$ & $\begin{array}{l}\text { Exploratory phase: } 15 \mathrm{ccRCC}+12 \mathrm{HC} ; \\
\text { Validation phase: } 90 \mathrm{RCC}(73 \mathrm{ccRCC}, 8 \mathrm{pRCC} \\
\text { and } 9 \mathrm{chRCC})+35 \mathrm{HC}\end{array}$ & Serum & $\begin{array}{l}\text { miRNeasy Mini Kit } \\
\text { (Qiagen) }\end{array}$ & TLDA & $\begin{array}{l}\text { qRT-PCR (TaqMan) } \\
\text { (miR-16) }\end{array}$ & $\begin{array}{c}\operatorname{miR}-378 \uparrow \\
\operatorname{miR}-451 \\
\text { miR-378 and miR-451 }\end{array}$ & $\begin{array}{l}0.71 \\
0.77 \\
0.86\end{array}$ & $\begin{array}{l}70.0 \\
81.0 \\
81.0\end{array}$ & $\begin{array}{l}60.0 \\
77.0 \\
83.0\end{array}$ & Dg \\
\hline $\begin{array}{l}\text { Hauser et al., } \\
2012[62]^{* *}\end{array}$ & $\begin{array}{l}\text { Discovery cohort: } 25 \text { ccRCC + } 25 \text { cancer-free } \\
\text { controls; } \\
\text { Validation cohort: } 117 \text { RCC }(104 \text { ccRCC, } 10 \\
\text { pRCC, } 1 \text { chRCC, } 1 \text { sRCC) + } 123 \text { CTRL (109 } \\
\text { cancer-free, } 14 \text { BRT) }\end{array}$ & Serum & $\begin{array}{l}\text { mirVana PARIS Kit } \\
\text { (Applied Biosystem) }\end{array}$ & $\begin{array}{l}\text { From Wulfken et al., } \\
\qquad 2011\end{array}$ & $\begin{array}{l}\text { qRT-PCR (TaqMan) } \\
\quad(\text { miR-39) }\end{array}$ & $\operatorname{miR}-378 \uparrow$ & 0.73 & na & na & na \\
\hline $\begin{array}{l}\text { Zhao et al., } \\
2013[63]\end{array}$ & $68 \mathrm{ccRCC}+42 \mathrm{HC}$ & Serum & MicroMini Kit (Qiagen) & From literature & $\begin{array}{l}\text { qRT-PCR (Qiagen) (5S } \\
\text { rRNA) }\end{array}$ & $\operatorname{miR}-210 \uparrow$ & 0.87 & 81.0 & 79.4 & Dg \\
\hline $\begin{array}{l}\text { Cheng et al., } \\
2013[64]\end{array}$ & $12 \mathrm{ccRCC}+12 \mathrm{BKL}$ & Serum & $\begin{array}{l}\text { mirVanaa }{ }^{\mathrm{TM}} \text { PARIS kit } \\
\text { (Applied Biosystems) }\end{array}$ & From literature & $\begin{array}{l}\text { qRT-PCR (Takara) } \\
\text { (RNU6) }\end{array}$ & $\begin{array}{r}\operatorname{miR}-34 \mathrm{a} \uparrow \\
\operatorname{miR}-21 \uparrow \\
\operatorname{miR}-224 \uparrow \\
\operatorname{miR}-141 \downarrow\end{array}$ & $\begin{array}{l}\text { na } \\
\text { na } \\
\text { na } \\
\text { na }\end{array}$ & $\begin{array}{l}\text { na } \\
\text { na } \\
\text { na } \\
\text { na }\end{array}$ & $\begin{array}{l}\text { na } \\
\text { na } \\
\text { na } \\
\text { na }\end{array}$ & Dg \\
\hline $\begin{array}{l}\text { Zhao et al., } \\
2013[65]\end{array}$ & $30 \mathrm{ccRCC}+50 \mathrm{HC}$ & Plasma & TRIzol (Invitrogen) & From literature & qRT-PCR (Takara) & miR-187 $\downarrow$ & na & na & na & na \\
\hline $\begin{array}{l}\text { Iwamato et al., } \\
2014[66]\end{array}$ & $34 \mathrm{ccRCC}+23 \mathrm{HC}$ & Serum & $\begin{array}{l}\text { microRNA extractor SP kit } \\
\text { (Wako) }\end{array}$ & From literature & $\begin{array}{l}\text { qRT-PCR (TaqMan) } \\
\text { (miR-16) }\end{array}$ & $\operatorname{miR}-210 \uparrow$ & 0.77 & 65 & 83 & Dg \\
\hline $\begin{array}{l}\text { Teixeira et al., } \\
\quad 2014[67]\end{array}$ & $43 \mathrm{RCC}(31 \mathrm{ccRCC}+12$ others) $+34 \mathrm{HC}$ & Plasma & $\begin{array}{c}\text { mirVana } \\
\left.{\left.\text { (Ambion }{ }^{\circledR}\right)}^{\mathrm{TM}}\right)\end{array}$ & From literature & $\begin{array}{l}\text { qRT-PCR (TaqMan) } \\
\text { (RNU44) }\end{array}$ & $\begin{array}{l}\operatorname{miR}-221 \uparrow \\
\operatorname{miR}-222 \uparrow \\
\end{array}$ & $\begin{array}{c}0.70 \\
\text { na }\end{array}$ & $\begin{array}{c}72.5 \\
\text { na }\end{array}$ & $\begin{array}{c}33.3 \\
\text { na }\end{array}$ & $\mathrm{Dg} / \mathrm{Pg}$ \\
\hline $\begin{array}{l}\text { Wang et al., } \\
2015[68]\end{array}$ & $\begin{array}{l}\text { Screening phase: } 25 \text { ccRCC }+25 \text { controls (ns); } \\
\text { Validation phase: } 107 \text { ccRCC (randomly divided } \\
\text { into two sets: } 28+79)+107 \text { controls (ns) }\end{array}$ & Serum & Phenol/chloroform & TLDA & $\begin{array}{l}\text { qRT-PCR (TaqMan) } \\
\quad \text { (let-7d/g/i) }\end{array}$ & $\begin{array}{c}\text { miR-193a-3p } \uparrow \\
\text { miR-362 } \uparrow \\
\text { miR-572 } \uparrow \\
\text { miR-28-5p } \downarrow \\
\text { miR-378 } \downarrow \\
\text { Panel of all } 5 \text { miRNAs }\end{array}$ & $\begin{array}{l}\text { na } \\
\text { na } \\
\text { na } \\
\text { na } \\
\text { na } \\
0.80\end{array}$ & $\begin{array}{c}\text { na } \\
\text { na } \\
\text { na } \\
\text { na } \\
\text { na } \\
80.0\end{array}$ & $\begin{array}{c}\text { na } \\
\text { na } \\
\text { na } \\
\text { na } \\
\text { na } \\
71.0\end{array}$ & Dg \\
\hline $\begin{array}{l}\text { Zhang et al., } \\
\text { 2015 [69] }\end{array}$ & $82 \mathrm{RCC}(\mathrm{ns})+19 \mathrm{HC}$ & Serum & $\begin{array}{c}\text { TRIzol } \\
\text { (Invitrogen) }\end{array}$ & From literature & $\begin{array}{l}\text { qRT-PCR (Takara) } \\
\text { (RNU6) }\end{array}$ & $\operatorname{miR}-183 \uparrow$ & na & na & na & na \\
\hline $\begin{array}{l}\text { Fedorko et al., } \\
2015[70]^{* *}\end{array}$ & $\begin{array}{c}195 \mathrm{RCC}(157 \mathrm{ccRCC}, 26 \mathrm{pRCC} \text {, and } 12 \mathrm{chRCC})+ \\
100 \mathrm{HC}\end{array}$ & Serum & $\begin{array}{l}\text { miRNeasy Mini Kit } \\
\text { (Qiagen) }\end{array}$ & From literature & qRT-PCR (TaqMan) & $\begin{array}{c}\operatorname{miR}-378 \uparrow \\
\operatorname{miR}-210 \uparrow \\
\text { miR-378 and miR-210 }\end{array}$ & $\begin{array}{l}0.82 \\
0.74 \\
0.85 \\
\end{array}$ & $\begin{array}{c}\text { na } \\
\text { na } \\
80.0\end{array}$ & $\begin{array}{c}\text { na } \\
\text { na } \\
78.0\end{array}$ & $\mathrm{Dg} / \mathrm{Pg}$ \\
\hline $\begin{array}{c}\text { Liu et al., } 2015 \\
{[711]}\end{array}$ & $32 \mathrm{RCC}(\mathrm{ns})+32 \mathrm{HC}$ & Serum & TRIzol (Invitrogen) & From literature & $\begin{array}{l}\text { qRT-PCR (BulgeLoop) } \\
\text { (RNU6) }\end{array}$ & $\operatorname{miR}-210 \uparrow$ & na & na & na & na \\
\hline $\begin{array}{l}\text { Zhang et al., } \\
2016[72]^{* * *}\end{array}$ & $82 \mathrm{RCC}+80 \mathrm{HC}$ & Serum & MicroMini kit (Qiagen) & From literature & $\begin{array}{c}\text { qRT-PCR (Qiagen) } \\
\text { (RNU6) }\end{array}$ & $\begin{array}{l}\operatorname{miR}-210 \uparrow \\
\operatorname{miR}-1233 \uparrow\end{array}$ & $\begin{array}{l}0.69 \\
0.82 \\
\end{array}$ & $\begin{array}{l}70.0 \\
81.0\end{array}$ & $\begin{array}{l}62.2 \\
76.0 \\
\end{array}$ & Dg \\
\hline
\end{tabular}


Table 2. Cont.

\begin{tabular}{|c|c|c|c|c|c|c|c|c|c|c|}
\hline Reference & Sample Size & Sample & RNA Isolation & Biomarker Selection & Method (Reference) & $\begin{array}{c}\text { Biomarker Studied, } \\
\text { Regulation }\end{array}$ & AUC & $\begin{array}{l}\text { DS } \\
(\%)\end{array}$ & $\begin{array}{l}\text { DSp } \\
(\%)\end{array}$ & $\begin{array}{l}\text { Type of } \\
\text { Marker }\end{array}$ \\
\hline $\begin{array}{l}\text { Tusong et al., } \\
2016[73]\end{array}$ & $30 \mathrm{ccRCC}+30 \mathrm{HC}$ & Serum & $\begin{array}{c}\text { mirVana PARIS Kit } \\
\text { (Ambion) }\end{array}$ & From literature & $\begin{array}{c}\text { qRT-PCR (Maxima) } \\
\text { (RNU6) }\end{array}$ & $\underset{\operatorname{miR}-106 a \uparrow}{\operatorname{miR}-21 \uparrow}$ & $\begin{array}{l}0.87 \\
0.82\end{array}$ & $\begin{array}{l}77.3 \\
86.7\end{array}$ & $\begin{array}{l}96.4 \\
70.0\end{array}$ & $\operatorname{Dg}$ \\
\hline $\begin{array}{l}\text { Butz et al., } \\
2016[74]^{* * *}\end{array}$ & $\begin{array}{c}\text { Discovery cohort: } 28 \text { ccRCC + } 18 \text { HC; } \\
\text { Validation cohort: } 105 \text { (81 ccRCC, 24 BRT) + } \\
33 \text { HC }\end{array}$ & Urine sediments & $\begin{array}{c}\text { miRNeasy Serum/Plasma } \\
\text { Kit (Qiagen) }\end{array}$ & $\begin{array}{l}\text { Screening of } 754 \\
\text { miRNA by qRT-PCR } \\
\text { (TaqMan) }\end{array}$ & $\begin{array}{l}\text { qRT-PCR (TaqMan) } \\
\text { (miR-16-5p-miR-106a- } \\
\text { 5p) }\end{array}$ & $\begin{array}{c}\text { miR-126-3p and } \\
\text { miR-34b-5p } \downarrow \\
\text { miR-126-3p and } \\
\text { miR-49a } \uparrow \\
\text { miR-150-5p/miR-126-3p } \downarrow \\
\text { miR-126-3p and } \\
\text { miR-486-5p }\end{array}$ & $\begin{array}{l}0.79 \\
0.84 \\
0.77 \\
0.85\end{array}$ & $\begin{array}{l}83.8 \\
72.5 \\
75.0\end{array}$ & $\begin{array}{l}62.5 \\
75.9 \\
87.5\end{array}$ & Dg \\
\hline $\begin{array}{c}\text { Li at al, } 2017 \\
{[75]}\end{array}$ & $75 \mathrm{ccRCC}+45 \mathrm{HC}$ & $\begin{array}{c}\text { Urine } \\
\text { supernatant }\end{array}$ & Micro Mini Kit (Qiagen) & From literature & $\begin{array}{l}\text { qRT-PCR (Qiagen) } \\
\text { (cel-miR-39) }\end{array}$ & $\operatorname{miR}-210 \uparrow$ & 0.76 & 57.8 & 80.0 & $\operatorname{Dg}$ \\
\hline $\begin{array}{l}\text { Yadav et al., } \\
2017 \text { [76] }\end{array}$ & $\begin{array}{c}30 \text { ccRCC }+15 \text { controls with non-renal benign } \\
\text { diseases (urethral stricture or benign prostatic } \\
\text { enlargement) }\end{array}$ & Serum & $\begin{array}{c}\text { miRNA } \\
\text { (Qiagen) }\end{array}$ & From literature & $\begin{array}{l}\text { qRT-PCR (Qiagen) } \\
\quad(\text { cel-miR-39) }\end{array}$ & $\begin{array}{c}\text { miR-34a } \downarrow \\
\text { miR-141 } \\
\text { miR-1233 } \\
\text { miR-141 and miR-1233 } \\
\text { miR-1233 and miR-34a } \\
\text { miR-141 and miR-34a } \\
\text { miR-34a, miR-141, and } \\
\text { miR-1233 }\end{array}$ & $\begin{array}{l}0.92 \\
0.78 \\
0.97 \\
\text { na } \\
\text { na } \\
\text { na } \\
\text { na }\end{array}$ & $\begin{array}{c}80.7 \\
75.0 \\
93.3 \\
100 \\
96.6 \\
73.3 \\
100\end{array}$ & $\begin{array}{l}80.0 \\
73.3 \\
100 \\
73.3 \\
80.0 \\
60.0 \\
60.0\end{array}$ & Dg \\
\hline $\begin{array}{l}\text { Chanudet } \\
\text { et al., } \\
2017[77]^{* *}\end{array}$ & $94 \mathrm{ccRCC}+100$ controls (ns) & Plasma & $\begin{array}{l}\text { NucleoSpin }{ }^{\circledR} \text { miRNA } \\
\text { Plasma kit } \\
\text { (Macherey-Nagel). }\end{array}$ & $\begin{array}{l}\text { TaqMan arrays }(\mathrm{A}+\mathrm{B} \\
\text { cards) (RNU6 and } \\
\text { let-7g/d/i) }\end{array}$ & na & $\begin{array}{c}\text { miR-150 } \downarrow \\
\text { miR-451 } \\
\text { miR-451 and miR-26b }\end{array}$ & $\begin{array}{l}\mathrm{na} \\
0.64 \\
0.66 \\
\end{array}$ & $\begin{array}{l}\text { na } \\
\text { na } \\
\text { na }\end{array}$ & $\begin{array}{l}\text { na } \\
\text { na } \\
\text { na }\end{array}$ & $\mathrm{Pg}$ \\
\hline $\begin{array}{l}\text { Du et al,, } 2017 \\
{[78]^{* * *}}\end{array}$ & $\begin{array}{c}\text { Screening cohort: } 44 \text { RCC }(40 \mathrm{ccRCC}+2 \mathrm{pRCC}+ \\
2 \mathrm{uRCC}) \\
\text { Validation cohort: } 65 \text { RCC }(52 \mathrm{ccRCC}, 6 \mathrm{pRCC}, 2 \\
\text { chRCC, and } 5 \text { uRCC) }\end{array}$ & Plasma & $\begin{array}{l}\text { miRNeasy Micro Kit } \\
\text { (Qiagen) }\end{array}$ & $\begin{array}{l}\text { RNA sequencing } \\
\text { (Illumina HiSeq2000) }\end{array}$ & $\begin{array}{l}\text { qRT-PCR (TaqMan) } \\
\text { (miR-127-3p) }\end{array}$ & $\begin{array}{c}\text { miR-let-7i-5p } \\
\text { hsa-miR-190b } \\
\text { hsa-miR-26a-1-3p } \\
\text { hsa-miR-145-3p } \\
\text { hsa-miR-200a-3p } \\
\text { hsa-miR-9-5p } \\
\text { hsa-miR-615-3p }\end{array}$ & $\begin{array}{l}\text { na } \\
\text { na } \\
\text { na } \\
\text { na } \\
\text { na } \\
\text { na } \\
\text { na }\end{array}$ & $\begin{array}{l}\text { na } \\
\text { na } \\
\text { na } \\
\text { na } \\
\text { na } \\
\text { na } \\
\text { na }\end{array}$ & $\begin{array}{l}\text { na } \\
\text { na } \\
\text { na } \\
\text { na } \\
\text { na } \\
\text { na } \\
\text { na }\end{array}$ & $\mathrm{Pg}$ \\
\hline $\begin{array}{c}\text { Lou et al., } \\
{[\text { [79] }}\end{array}$ & $\begin{array}{l}\text { Discovery cohort: } 10 \text { (ccRCC } 5 \text { preoperative and } \\
7 \text { days after operation); } \\
\text { Validation cohort: } 153(106 \text { ccRCC }+19 \text { ncRCC + } \\
28 \text { AML }+123 \mathrm{HC}\end{array}$ & Plasma & $\begin{array}{c}\text { TRIReagent BD } \\
\text { (Molecular Research) }\end{array}$ & $\begin{array}{l}\text { miRNA microarray } \\
\text { (Agilent) }\end{array}$ & $\begin{array}{c}\text { qRT-PCR (Thermo) } \\
\text { (RNU6B, cel-miR-39, } \\
\text { miR-320c) }\end{array}$ & $\operatorname{miR}-144-3 p \uparrow$ & 0.91 & 87.1 & 83 & $\mathrm{Dg} / \mathrm{Pg}$ \\
\hline $\begin{array}{l}\text { Petrozza et al., } \\
2017 \text { [80] }\end{array}$ & $38 \mathrm{ccRCC}+10 \mathrm{HC}$ from two independent cohorts & Whole urine & $\begin{array}{c}\text { miRNAeasy } \\
\text { serum/plasma kit } \\
\text { (Qiagen) }\end{array}$ & $\begin{array}{l}\text { From previous study } \\
\text { by the same group }\end{array}$ & $\begin{array}{l}\text { qRT-PCR (Qiagen) } \\
\text { (Spike-In Control } \\
\text { (Qiagen)) }\end{array}$ & $\operatorname{miR}-210-3 p \uparrow$ & na & na & na & na \\
\hline $\begin{array}{l}\text { Fedorko et al., } \\
2017 \text { [81] }\end{array}$ & $\begin{array}{c}69 \mathrm{ccRCC}+36 \mathrm{HC} \text { (surgically treated for various } \\
\text { benign urological conditions) }\end{array}$ & $\begin{array}{c}\text { Urine } \\
\text { supernatant }\end{array}$ & $\begin{array}{c}\text { Urine microRNA } \\
\text { Purification Kit (Norgen } \\
\text { Biotek) }\end{array}$ & From literature & $\begin{array}{l}\text { qRT-PCR (TaqMan) } \\
\text { (syntetic miRNA oligo } \\
\text { (IDT)) }\end{array}$ & $\begin{array}{c}\text { let-7a } \\
\text { let-7b } \\
\text { let-7c } \\
\text { let-7d } \\
\text { let-7e } \\
\text { let-7g } \\
\text { Panel of all } 6 \text { miRNAs }\end{array}$ & $\begin{array}{l}0.83 \\
0.75 \\
0.67 \\
0.66 \\
0.65 \\
0.69 \\
0.83\end{array}$ & $\begin{array}{l}71.0 \\
73.0 \\
65.0 \\
66.0 \\
62.0 \\
70.0 \\
\text { na }\end{array}$ & $\begin{array}{l}81.0 \\
67.0 \\
62.0 \\
61.0 \\
61.0 \\
60.0 \\
\text { na }\end{array}$ & $\operatorname{Dg}$ \\
\hline $\begin{array}{l}\text { Wang et al., } \\
2017 \text { [82] }\end{array}$ & 27 RCC (ns) +28 controls & Serum & na & From literature & $\begin{array}{l}\text { qRT-PCR (Sangon } \\
\text { Biotech) (GAPDH) }\end{array}$ & $\operatorname{miR}-429 \uparrow$ & na & na & na & $\mathrm{Dg} / \mathrm{Pg}$ \\
\hline
\end{tabular}


Table 2. Cont.

\begin{tabular}{|c|c|c|c|c|c|c|c|c|c|c|}
\hline Reference & Sample Size & Sample & RNA Isolation & Biomarker Selection & Method (Reference) & $\begin{array}{c}\text { Biomarker Studied, } \\
\text { Regulation }\end{array}$ & AUC & $\begin{array}{l}\text { DS } \\
(\%)\end{array}$ & $\begin{array}{l}\text { DSp } \\
(\%)\end{array}$ & $\begin{array}{l}\text { Type of } \\
\text { Marker }\end{array}$ \\
\hline $\begin{array}{l}\text { Dias et al., } \\
2017[83]\end{array}$ & $54 \mathrm{RCC}(39 \mathrm{ccRCC}+15$ other $)+50 \mathrm{HC}$ & Plasma & $\underset{\left(G^{\text {Grisp }}{ }^{\circledR}\right)}{\text { GRS kit }}$ & From literature & $\begin{array}{l}\text { qRT-PCR (TaqMan) } \\
\text { (RNU48) }\end{array}$ & $\begin{array}{l}* \mathrm{miR}-210 \uparrow \\
* \mathrm{miR}-218 \uparrow \\
* \mathrm{miR}-221 \uparrow \\
* \mathrm{miR}-1233 \uparrow\end{array}$ & $\begin{array}{l}0.70 \\
\text { na } \\
0.62 \\
0.61\end{array}$ & $\begin{array}{c}60.9 \\
\text { na } \\
71.4 \\
39.1\end{array}$ & $\begin{array}{l}73.1 \\
\text { na } \\
65.0 \\
92.6\end{array}$ & $\operatorname{Pg}$ \\
\hline $\begin{array}{l}\text { Li et al., } 2017 \\
{[84]^{* *}}\end{array}$ & $139 \mathrm{RCC}+139 \mathrm{HC}$ & Serum & TRIzol (Invitrogen) & From literature & $\begin{array}{l}\text { qRT-PCR (Takara) } \\
\text { (RNU6) }\end{array}$ & $\mathrm{miR}-22 \downarrow$ & na & na & na & $\operatorname{Pg}$ \\
\hline \multirow{2}{*}{$\begin{array}{l}\text { Heinemann } \\
\text { et al., 2018 [85] }\end{array}$} & $\begin{array}{c}\text { Discovery cohort: } 18 \text { ccRCC }+8 \text { BRT ( } 4 \text { OCT and } \\
4 \text { complicated renal cysts); }\end{array}$ & \multirow[t]{2}{*}{ Serum } & \multirow{2}{*}{$\begin{array}{c}\text { mirVana PARIS } \\
\text { Kit(Thermo Fisher } \\
\text { Scientific) }\end{array}$} & \multirow{2}{*}{$\begin{array}{l}\text { Sequencing (Illumina } \\
\text { NextSeq 500) }\end{array}$} & \multirow{2}{*}{$\begin{array}{l}\text { qRT-PCR (Qiagen) } \\
\text { (miR-16, miR-191-5p, } \\
\text { miR-320a) }\end{array}$} & \multirow{2}{*}{$\begin{array}{c}\text { miR-122-5p } \downarrow \\
\text { miR-206 } \downarrow \\
\text { miR-122-5p and } \\
\text { miR-206 }\end{array}$} & $\begin{array}{l}0.71 \\
0.73\end{array}$ & $\begin{array}{c}\mathrm{na} \\
83.8\end{array}$ & $\begin{array}{c}\text { na } \\
57.1\end{array}$ & \multirow[t]{2}{*}{$\operatorname{Pg}$} \\
\hline & $\begin{array}{l}\text { Validation cohort: } 115(68 \text { ccRCC, } 17 \text { OCT, } 14 \\
\text { AML, and } 16 \text { complicated renal cysts) + } 28 \text { HC }\end{array}$ & & & & & & 0.73 & na & na & \\
\hline $\begin{array}{l}\text { Chen et al., } \\
2018[87]\end{array}$ & $66 \mathrm{ccRCC}+67 \mathrm{HC}$ & Plasma & $\begin{array}{l}\text { TRIzol (Thermo Fisher } \\
\text { Scientific) }\end{array}$ & $\begin{array}{l}\text { From previous study } \\
\text { by the same group }\end{array}$ & $\begin{array}{l}\text { qRT-PCR (Invitrogen) } \\
\quad \text { (cel-miR-39) }\end{array}$ & $\begin{array}{c}\operatorname{miR}-210 \uparrow \\
\operatorname{miR}-224 \uparrow \\
\text { miR210 and miR-224 }\end{array}$ & $\begin{array}{l}0.68 \\
0.61 \\
0.66\end{array}$ & $\begin{array}{l}89.6 \\
88.1 \\
92.5\end{array}$ & $\begin{array}{l}48.5 \\
40.9 \\
45.5\end{array}$ & Dg \\
\hline $\begin{array}{l}\text { Wang et al., } \\
2018[88]^{* * *}\end{array}$ & $\begin{array}{l}\text { Discovery cohort: } 5 \text { ccRCC + paired NRT tissue; } \\
\text { Validation cohort: } 45 \text { RCC (ns) + 30 HC } \\
\end{array}$ & Serum & TRIzol(Invitrogen) & $\begin{array}{l}\text { miRNA Microarray } \\
\text { (Agilent Technologie) }\end{array}$ & $\begin{array}{c}\text { qRT-PCR (Invitrogen) } \\
\text { (miR-16) }\end{array}$ & $\begin{array}{c}\operatorname{miR}-210 \uparrow \\
\operatorname{miR}-210 \uparrow(E x o)\end{array}$ & $\begin{array}{l}0.79 \\
0.88\end{array}$ & $\begin{array}{l}67.5 \\
82.5\end{array}$ & $\begin{array}{l}70.0 \\
80.0\end{array}$ & $\operatorname{Dg}$ \\
\hline $\begin{array}{l}\text { Song et al., } \\
2019[89]^{* * *}\end{array}$ & $70 \mathrm{ccRCC}+30 \mathrm{HC}$ & Urine sediments & $\begin{array}{c}\text { TRIzol Plus RNA } \\
\text { Purification Kit (Life } \\
\text { Technologies) } \\
\end{array}$ & $\begin{array}{l}\text { Sequencing (Illumina } \\
\text { HiSeq 2000) }\end{array}$ & qRT-PCR (TaqMan) & miR-30c-5p $\downarrow$ & 0.82 & 68.6 & 100 & $\operatorname{Dg}$ \\
\hline $\begin{array}{l}\text { Liu et al., } 2019 \\
{[90]}\end{array}$ & $\begin{array}{l}\text { Testing stage: } 10 \mathrm{ccRCC}+10 \mathrm{HC} \\
\text { Validation stage: } 85 \mathrm{ccRCC}+35 \mathrm{HC}\end{array}$ & Serum & $\begin{array}{l}\text { TRI zol }{ }^{\circledR} \mathrm{LS} \\
\text { (Invitrogen) }\end{array}$ & GEO + TCGA & $\begin{array}{c}\text { qRT-PCR } \\
\text { (GenePharma) (miR-39) }\end{array}$ & $\begin{array}{c}\operatorname{miR}-508-3 \mathrm{p} \\
\mathrm{miR}-885-5 \mathrm{p} \\
\mathrm{miR}-508-3 \mathrm{p} \text { and } \\
\text { miR-885-5p }\end{array}$ & $\begin{array}{l}0.80 \\
0.87\end{array}$ & $\begin{array}{l}\text { na } \\
\text { na }\end{array}$ & $\begin{array}{l}\text { na } \\
\text { na }\end{array}$ & Dg \\
\hline $\begin{array}{l}\text { Zhao et al., } \\
2019 \text { [91] }\end{array}$ & $50 \mathrm{ccRCC}+74 \mathrm{HC}$ & Serum & $\begin{array}{l}\text { miRNeasy Serum/Plasma } \\
\text { Kit (Qiagen) }\end{array}$ & TCGA & $\begin{array}{l}\text { qRT-PCR (Qiagen) } \\
\text { (cel-miR-54) }\end{array}$ & $\operatorname{miR}-625-3 p \downarrow$ & 0.79 & 70.3 & 80.0 & $\operatorname{Dg}$ \\
\hline $\begin{array}{l}\text { Petrozza et al., } \\
\quad 2019[92]\end{array}$ & $21 \mathrm{ccRCC}+16 \mathrm{HC}$ & Whole urine & $\begin{array}{l}\text { miRNeasy Serum/Plasma } \\
\text { Kit (Qiagen) }\end{array}$ & $\begin{array}{l}\text { From previous study } \\
\text { by the same group }\end{array}$ & $\begin{array}{l}\text { qRT-PCR (Qiagen) (C. } \\
\text { elegans miR-39) }\end{array}$ & $\operatorname{miR}-210-3 p \uparrow$ & na & na & na & na \\
\hline $\begin{array}{l}\text { Di Meo et al., } \\
2020[93]\end{array}$ & $\begin{array}{l}\text { Discovery cohort: } 9 \text { SRM }(6 \text { ccRCC }+3 \text { OCT }) \\
\text { Validation cohort: } 71 \text { SRM }(44 \text { ccRCC + } 27 \text { OCT })\end{array}$ & Urine & $\begin{array}{l}\text { miRNeasy Serum/Plasma } \\
\text { Kit (Qiagen) }\end{array}$ & $\begin{array}{l}\text { Screening of } 754 \\
\text { miRNA by qRT-PCR } \\
\text { (TaqMan) }\end{array}$ & $\begin{array}{l}\text { qRT-PCR (TaqMan) } \\
\text { (Geometric mean of } \\
\text { miR-204, miR-1825, } \\
\text { RNU48, and RNU6) }\end{array}$ & $\begin{array}{c}\text { has-miR-432-5p } \uparrow \\
\text { has-miR-532-5p } \uparrow \\
\text { has-miR-10a-5p } \uparrow \\
\text { has-miR-144-3p } \uparrow \\
\text { has-miR-28-3p } \uparrow \\
\text { has-miR-326 } \uparrow \\
\text { has-miR-328-3p } \uparrow \\
\text { has-miR-603 } \uparrow \\
\text { has-miR-93-3p } \uparrow\end{array}$ & $\begin{array}{l}0.71 \\
0.70 \\
0.66 \\
0.68 \\
0.65 \\
0.68 \\
0.65 \\
0.67 \\
0.68\end{array}$ & $\begin{array}{l}\text { na } \\
\text { na } \\
\text { na } \\
\text { na } \\
\text { na } \\
\text { na } \\
\text { na } \\
\text { na } \\
\text { na }\end{array}$ & $\begin{array}{l}\text { na } \\
\text { na } \\
\text { na } \\
\text { na } \\
\text { na } \\
\text { na } \\
\text { na } \\
\text { na } \\
\text { na }\end{array}$ & $\mathrm{Pg}$ \\
\hline $\begin{array}{l}\text { Xiao et al., } \\
2020[94]\end{array}$ & $\begin{array}{c}\text { Discovery cohort: } 5 \text { ccRCC (preoperative and } 7 \\
\text { days after surgery); } \\
\text { Validation cohort: } 18 \text { ccRCC (preoperative and } 7 \\
\text { days after surgery) }\end{array}$ & Plasma & Trizol (Thermo) & $\begin{array}{l}\text { miRNA Microarray } \\
\text { (Agilent Technologies) }\end{array}$ & $\begin{array}{l}\text { qRT-PCR (Thermo) } \\
\text { (RNU6) }\end{array}$ & $\operatorname{miR}-765$ & na & na & na & na \\
\hline \multirow{2}{*}{$\begin{array}{c}\text { Kalogiroum } \\
\text { et al., } \\
2020[95]^{* *}\end{array}$} & \multirow{2}{*}{$\begin{array}{c}67 \text { pRCC (34 pRCC type 1, } 33 \text { pRCC type } 2)+33 \\
\text { controls }\end{array}$} & \multirow{2}{*}{ Serum } & \multirow{2}{*}{$\begin{array}{l}\text { Exiqon RNA services } \\
\text { (http:// /www.exiqon.com, } \\
\text { accessed on } 1 \text { August 2021) }\end{array}$} & \multirow{2}{*}{$\begin{array}{l}\text { From publications, } \\
\text { TCGA }\end{array}$} & \multirow{2}{*}{$\begin{array}{c}\text { qRT-PCR (Exiqon) } \\
\text { (miR-23a-3p, } \\
\text { miR-191-5p, and } \\
\text { miR-103a-3p) } \\
\end{array}$} & \multirow{2}{*}{$\begin{array}{c}\text { miR-21-5p } \uparrow \\
\text { miR-210-3p } \downarrow \\
\text { miR-21-5p and } \\
\text { miR-210-3p } \\
\end{array}$} & $\begin{array}{l}0.57 \\
0.71\end{array}$ & $\begin{array}{l}\text { na } \\
\text { na }\end{array}$ & $\begin{array}{l}\text { na } \\
\text { na }\end{array}$ & \multirow{2}{*}{ na } \\
\hline & & & & & & & 0.72 & na & na & \\
\hline
\end{tabular}


Table 2. Cont.

\begin{tabular}{|c|c|c|c|c|c|c|c|c|c|c|}
\hline Reference & Sample Size & Sample & RNA Isolation & $\begin{array}{l}\text { Biomarker } \\
\text { Selection }\end{array}$ & Method (Reference) & $\begin{array}{c}\text { Biomarker Studied, } \\
\text { Regulation }\end{array}$ & AUC & $\begin{array}{l}\mathrm{DS} \\
(\%)\end{array}$ & $\begin{array}{l}\text { DSp } \\
(\%)\end{array}$ & $\begin{array}{l}\text { Type of } \\
\text { Marker }\end{array}$ \\
\hline $\begin{array}{c}\text { Dias et al., } 2020 \\
{[96]^{* * *}}\end{array}$ & $\begin{array}{l}\text { Group A: } 32 \text { ccRCC (localized); Group B: } 37 \\
\text { ccRCC (metastatic) }\end{array}$ & Plasma & $\begin{array}{l}\text { Plasma/Serum } \\
\text { RNAPurification } \\
\text { Mini Kit (Norgen } \\
\text { Biotek Corporation) }\end{array}$ & $\begin{array}{l}\text { From publications } \\
\text { (related to } \\
\text { hypoxia) }\end{array}$ & $\begin{array}{l}\text { qRT-PCR (TaqMan) } \\
\text { (hsa-let7a-5p, } \\
\text { hsa-miR-16-5p) }\end{array}$ & $\begin{array}{c}\text { hsa-miR-25-3p } \\
\text { hsa-miR-126-5p } \\
\text { hsa-miR-200c-3p } \\
\text { hsa-miR-301a-3p } \\
\text { hsa-miR-1293 }\end{array}$ & $\begin{array}{l}\text { na } \\
\text { na } \\
\text { na } \\
\text { na } \\
\text { na }\end{array}$ & $\begin{array}{l}\text { na } \\
\text { na } \\
\text { na } \\
\text { na } \\
\text { na }\end{array}$ & $\begin{array}{l}\text { na } \\
\text { na } \\
\text { na } \\
\text { na } \\
\text { na }\end{array}$ & $\operatorname{Pg}$ \\
\hline $\begin{array}{c}\text { Wang et al., } 2020 \\
{[97]}\end{array}$ & $12 \mathrm{ccRCC}$ (preoperative and postoperative) & Plasma & na & GEO & $\begin{array}{l}\text { qRT-PCR } \\
\text { (na) } \\
\text { (RNU6) }\end{array}$ & miR-483-5p & na & na & na & na \\
\hline $\begin{array}{c}\text { Huang et al., } 2020 \\
{[988]}\end{array}$ & $\begin{array}{l}\text { Screening stage: } 20 \mathrm{RCC}(\mathrm{ns})+20 \mathrm{HC} \text {; } \\
\text { Testing stage: } 30 \mathrm{RCC}(\mathrm{ns})+30 \mathrm{HC} \text {; } \\
\text { Validation stage: } 76 \mathrm{RCC}(\mathrm{ns})+80 \mathrm{HC}\end{array}$ & Serum & $\begin{array}{l}\text { TRIzol } \\
\text { LS(Invitrogen) }\end{array}$ & From publications & $\begin{array}{l}\text { qRT-PCR (Takara) } \\
\text { (cel-miR-39) }\end{array}$ & $\begin{array}{c}\operatorname{miR}-224-5 \mathrm{p} \uparrow \\
\mathrm{miR}-34 \mathrm{~b}-3 \mathrm{p} \downarrow \\
\mathrm{miR}-129-2-3 \mathrm{p} \downarrow \\
\mathrm{miR}-1 \mathrm{p} 2-5 \mathrm{p} \downarrow \\
\text { miR-224-5p, miR-34b-3p, } \\
\text { and miR-182-5p }\end{array}$ & $\begin{array}{l}0.69 \\
0.78 \\
0.69 \\
0.75 \\
0.86\end{array}$ & $\begin{array}{c}\text { na } \\
\text { na } \\
\text { na } \\
\text { na } \\
80.3\end{array}$ & $\begin{array}{c}\text { na } \\
\text { na } \\
\text { na } \\
\text { na } \\
66.3\end{array}$ & $\operatorname{Pg}$ \\
\hline $\begin{array}{c}\text { Xiao et al., } 2020 \\
{[99]^{* * *}}\end{array}$ & $\begin{array}{c}\text { Discovery cohort: } 5 \text { RCC }+5 \text { controls; } \\
\text { Validation cohort: } 22 \text { RCC }(18 \text { ccRCC }+4 \text { pRCC }) \\
+16 \mathrm{HC} \\
\end{array}$ & Plasma & $\begin{array}{l}\text { miRNeasy kit } \\
\text { (Qiagen) }\end{array}$ & $\begin{array}{l}\text { Sequencing } \\
\text { (Illumina } \\
\text { NovaSeq 6000) }\end{array}$ & $\begin{array}{l}\text { qRT-PCR (na) } \\
\text { (miR-16-5p) }\end{array}$ & $\begin{array}{c}\text { hsa-miR -92a-1-5p } \downarrow \\
\text { hsa-miR-424-3p } \uparrow \\
\text { hsa-miR-149-3p } \uparrow\end{array}$ & $\begin{array}{l}0.83 \\
0.77 \\
0.72 \\
\end{array}$ & $\begin{array}{l}87.5 \\
75.0 \\
75.0\end{array}$ & $\begin{array}{l}77.3 \\
81.8 \\
73.0\end{array}$ & Dg \\
\hline $\begin{array}{l}\text { Cochetti et al., } \\
2020[100]\end{array}$ & $13 \mathrm{ccRCC}+14 \mathrm{HC}$ & Whole urine & $\begin{array}{l}\text { miRNeasy Micro Kit } \\
\text { (Qiagen) }\end{array}$ & GEO & $\begin{array}{l}\text { qRT-PCR (Qiagen) } \\
\text { (miR-16, cel-miR-39, } \\
\text { and miRTC) }\end{array}$ & $\begin{array}{c}\text { miR-122 } \\
\text { miR-1271 } \\
\text { miR-15b } \\
\text { miR-122, miR-1271, and } \\
\text { miR-15b (7p-urinary } \\
\text { score) }\end{array}$ & $\begin{array}{l}0.82 \\
0.79 \\
0.59 \\
\\
0.96\end{array}$ & $\begin{array}{c}\text { na } \\
\text { na } \\
\text { na } \\
100\end{array}$ & $\begin{array}{l}\text { na } \\
\text { na } \\
\text { na } \\
86\end{array}$ & $\operatorname{Dg}$ \\
\hline
\end{tabular}

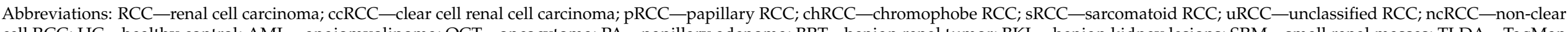

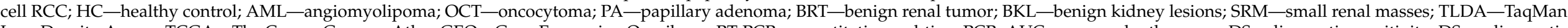

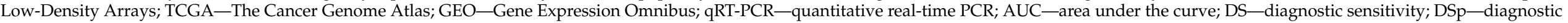

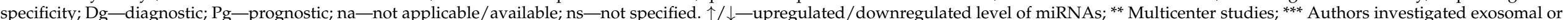
microvesicles derived miRNA. 
Twenty studies reported clinically relevant (AUC $\geq 0.75$ ) discriminating abilities of various miRNAs or their combinations, encompassing 33 distinct miRNAs in total (Table 2). The panels of miRNA were generally recommended to improve the accuracy of results and such panels were evaluated in the eight studies discussed. The highest diagnostic ability of such combinations was found by Liu et al. [90] for miR-508-3p and miR-885-5p, which had an AUC $=90$ in both, with testing and validation sets of serum samples, and by Cochetti et al. [100] for miR-122, miR-1271, and miR-15b, which had an AUC $=96$ in a very small set of urine samples. Yadav et al. [76] found an even better clinical value for only one miRNA, namely miR-1233, which had a superior AUC, equal to 0.97 , and a sensitivity and specificity of $93 \%$ and $100 \%$, respectively; however, only 30 ccRCC cases were included in this study. The requirement of validating such results in the independent and larger cohorts was perfectly conveyed in the multicenter study by Wulfken et al. [58], where the discriminating ability of the same miR-1233 reached only 0.67 and 0.59 of AUC in the testing and validation cohorts, respectively. Zhang et al. [72] also found a clinically useful AUC (0.82) for the exclusively exosomal miR-1233. It's worth mentioning that these inconsistencies among the studies may come from different qRT-PCR analysis and normalization methods as well. For example, Sanders et al. [102] demonstrated that cel-miR-39, which was also used in the studies by Yadav et al. and Wulfken et al., was effective for the normalization of circulating miRNA in patients with urological malignancies, including RCC; meanwhile, RNU6, which was used by Zhang et al., was not a stable, normalization control [87].

Among urine-based diagnostic biomarkers, the study of Butz et al. [74] is the worthiest of mention. The authors reported acceptable discriminative abilities (AUC $=0.77-0.85$ ) of various combinations of two exosomal miRNAs not only among ccRCC and healthy controls, but between healthy controls and small renal masses (SRM) and benign renal tumors (BRT) as well. Overall, miR-126-3p combined with miR-449a or miR-34b-5p could significantly distinguish ccRCC from healthy participants with an AUC of 0.84 and 0.79 , respectively. The combination of miR-126-3p and miR-449a or miR-126-3p and miR-34b-5p was also able to distinguish SRM or BRT from healthy controls with an AUC of 0.89/0.79 and an AUC of $0.77 / 0.82$, respectively. In addition, the authors found that after surgery, the expression of these miRNA returned to a level comparable with healthy control/status.

In many studies, changes of miRNA levels in the body fluid samples were observed after nephrectomy for treatment of RCC [60,63,70,72-75,79,80,84,86-88,92,94,96,97], suggesting the possibility of such miRNAs in follow-up monitoring of patients with RCC. In addition, the nine studies, encompassing 12 separate miRNAs, specifically miR-378 [70], miR-144-3p [79], miR-210 [83,88], miR-1233 [83], miR-22 [84] miR-122-5p, miR-206 [85], miR-15a [86], miR-508-3p, miR-885-5p [90], has-miR-328-3p [93], has-miR1293, and hasmiR-301-3p [96] reported the association between the level of particular miRNA and clinical-pathological parameters, including tumor size, tumor stage, Fuhrman grade, necrosis, and cancer progression or metastasis. In more detail, deregulated expression of miR-15a were correlated with tumor size; miR-378, miR-144-3p, miR-22, miR-206, miR-210, miR508-3p, and miR-885-5p were related with advanced tumor stage; miR-1233, miR-122-5p, miR-206, miR-210, miR-15a, miR-508-3p, and miR-885-5p with advanced tumor Fuhrman grade; miR-15a with tumor necrosis; and miR-210, miR-1233, miR-22, miR-508-3p, has-miR328-3p, has-miR1293, and has-miR-301-3p with tumor progression or metastasis.

The prognostic value of circulating miRNAs was reported in seven of the studies $[67,70,77,78,83,85,93]$; however, only four studies $[67,78,83,85]$ demonstrated that miRNAs expression could independently predict the survival of patients with RCC. The elevated expression level of miR-221 was associated with shorter OS and augmented the predictive ability of the tumor stage, Fuhrman grade, and patient age ( $\geq 60$ years) from HR: 4.7 to HR: 10.7 in the multivariate model [67]. However, Du et al. [78] related the lower expression of miR-let-7i-5p, hsa-miR-26a-1-3p, and hsa-miR-615-3p with shorter OS, and miR-let-7i-5p remained significantly associated with patient survival with an HR of 0.57 after adjusting for the MSKCC score (the most common scoring system used for prognosti- 
cation). Dias et al. [83] demonstrated the association between the increased plasma level of miR-210 and miR-1233 and cancer-specific survival (CSS), while the multivariate Cox regression model, using tumor TNM stage, Fuhrman grade, age ( $>60$ years), and gender as co-variants, demonstrated a higher risk of disease-specific death in patients characterized by a simultaneously higher level of miR-210, miR-221, and miR-1233, with an HR: 3.02. Heinemann et al. [85] showed an association between decreased levels of miR-122-5p and miR-206 and patients' CSS, PFS as well as OS, and a Cox regression model revealed miR-206 as an independent biomarker for PFS (HR: 3.5 while adjusted according to tumor TNM stage and grade). While circulating levels of miR-378, miR-150, and miR-328-3p were related to patients' disease-free survival, disease-specific survival, and overall survival, respectively, they lacked evidence as an independent prognostic factor in RCC [70,77,93]. It is worth mentioning that all miRNAs stated as independent prognostic biomarkers lacked internal validation, and only Heinemann et al. [85] included $>100$ samples, while other authors investigated $\leq 65$ samples.

MiR-210 was the most widely studied circulating miRNA in the case of RCC, and was discussed in the nine studies reviewed herein. Despite significantly different experimental conditions (different miRNA isolation kits, PCR reagents, and quantification strategies), all investigators found increased circulating miR-210 levels in patients with RCC as compared to healthy controls. It is well known that miR-210 is expressed in response to hypoxia, mainly through HIF- $1 \alpha$, a key player of renal carcinogenesis [103]. However, it is worth mentioning that the upregulation of circulating miR-210 was also found in various other malignancies, [104] as well as non-cancerous conditions [105,106], and further validations, with suitable controls, are mandatory. MiR-1233 was also an actively studied circulating miRNA found upregulated in RCC in four studies; however, its functions have remained unresolved thus far. MiR-378 was an extensively studied circulating miRNA, however, the findings were quite divergent. Comparing RCC patients and healthy individuals, three studies reported an increase in miR-378 levels, while one study demonstrated a decrease. MiR-378 may act as both a tumor suppressor (inhibit cell proliferation and invasion) [107] or onco-miR (promote cell proliferation, migration, and invasion) [108] depending on the particular tissue. Other miRNAs, including miR-141, miR-150, miR-21, miR-34a, miR-508$3 p$, miR-15a, and miR-210-3p, were also studied in more than one report, while most of the miRNAs were investigated in a single study only, thus validation is urgently required.

The lack of knowledge about the biological function and role of particular miRNAs in renal carcinogenesis is another major obstacle to their use in clinical settings. Thirteen studies attempted to determine the molecular function of particular miRNAs $[59,65,69,71,74,82-84,88,89,91,94,97]$ in renal carcinoma cells. Ten studies, encompassing nine distinct miRNAs, specifically miR-508-3p [59], miR-187 [65], miR-210 [71,88], miR-429 [82], miR-22 [84], miR-30c-5p [89], miR-625-3p [91], miR-765 [94], and miR-483-5p [98], significantly related their deregulation with either increased cell proliferation, migration, invasion, viability, and reduced apoptosis in vivo and, in some cases, with tumor growth in vivo $[65,89,94]$. In several of these studies, possible targets of the given miRNAs were investigated. Zhao et al. [65] revealed B7H3 as one of the miR-187 targets. Knockdown of B7H3 inhibited cell proliferation and migration, while downregulation of miR-187 reversed these processes [65]. Li et al. [84] showed that miR-22 inhibited cell proliferation and invasion by targeting epidermal growth factor receptor member ERBB3. Song et al. [89] reported the heat shock protein HSPA5 as the miR-30c-5p target. As the increased level of HSPA5 enhanced cell viability and colony formation ability, the downregulated miR-30c-5p contributed to tumor progression. Xiao et al. [94] discloses that miR-765 restrained cell proliferation, migration, and invasion by targeting endoplasmic reticulum protein PLP2, whose own expression is related with epithelial-mesenchymal transition (EMT) and G2M checkpoint, and, thus, with more aggressive tumors. Moreover, Wang et al. [97] showed the ability of miR-483-5p to inhibit cell migration and invasion through increased expression of E-cadherin and reduced expression of N-cadherin, the key markers of EMT. Interestingly, despite extensive research, the biological function of miR-210 in RCC was not widely investigated. Dias et al. [83] 
observed a relationship between acute hypoxia, miR-210 excretion, and the increased expression of the chemokine receptor CXCR4, which is related to cancer progression and metastasis. In addition, Wang et al. [88] revealed the simultaneously increased excretion of exosomal miR-210 and decreased expression of vacuole membrane protein VMP1, involved in cancer progression and metastasis, under hypoxic conditions in renal cancer cells. In summary, despite the knowledge discussed, an exact mechanism of action for the particular miRNAs in RCC, and especially the role of their excretion, is not clear thus far. Some authors showed that hypoxia, which is related to rapidly growing tumors, is part of the process by which renal cancer cells excrete such miRNAs [83,88]. In addition, it seems that exosomal miRNAs participate in intracellular communication among tumor-tumor or tumor-endothelial cells $[74,88]$ and possibly disseminate signals for cancer progression. However, it remains largely unknown whether and how exosomal miRNAs contribute to RCC development and progression.

In sum, despite some promising data, no expectations exist that miRNAs will soon be introduced as diagnostic or prognostic biomarkers, neither alone nor in combination with clinical-pathological factors. The comparability and repeatability of current results are disputable, despite the increasing number of miRNA studies. Unstandardized isolation and quantification techniques, as well as the heterogeneity of the study cohorts, and unresolved biological functions are the major hurdles in novel biomarkers research. Thus, the development of standardized methods and functional investigations are urgently needed.

\section{Biofluid lncRNAs as Biomarkers for Renal Cell Carcinoma}

Long noncoding RNAs (lncRNAs) are a class of single RNAs, $>200$ nucleotides in length, with no protein-coding potential [109]. LncRNAs are involved in gene expression control either by transcriptional regulation through recruiting of chromatin-modifying complexes or by post-transcriptional regulation through interaction with miRNAs, mRNAs, and proteins [110]. In recent years, lncRNAs were shown to contribute to the development of nearly all cancer types, including kidney cancer [111,112]. As in the case of miRNAs, lncRNAs are involved in many processes related to cancer development and progression, including regulation of the cell cycle, proliferation, apoptosis, senescence, migration, invasion, drug resistance, and so on [113-116]. LncRNAs expression is more tumor- and organ-specific than other RNA entities [117] and they are quite stable in tissue and body fluids such as urine and blood [118]. It is possible that, similar to miRNAs, IncRNAs are protected from RNase degradation by extracellular vesicles and by interactions with specific proteins $[119,120]$. Thus, lncRNAs may serve as highly specific non-invasive biomarkers and are of particular interest as they may provide more precise diagnostic and prognostic information.

Serum circulating lncRNA from RCC patients was first analyzed by Wu et al. [119]. The authors described five significantly down-regulated lncRNAs in ccRCC patients when compared to healthy controls with an AUC of $5 \operatorname{lncRNAs}$ panel equal to 0.90 and 0.82 for the training and testing sets of samples, respectively (Table 3). Moreover, the panel significantly distinguished ccRCC from benign renal tumors. A similar diagnostic potential was later reported for two single serum-derived lncRNAs, specifically GIHCG and LINC00887, which were investigated by He et al. [121] and Xie et al. [122], respectively. In addition, the investigators observed post-surgical reduction in levels of these lncRNAs in serum, and a higher expression of LINC00887 was related with a shorter OS, which suggested the possibility of using circulating lncRNAs for patient follow-up. Moreover, Qu et al. [110] provided plasma-circulating lncARSR as an independent prognostic factor for RCC patients with sunitinib therapy, by comparing the elevated level of lncARSR in the pre-therapy plasma of RCC patients suffering from progressive disease during sunitinib treatment to patients without progressive disease. 
Table 3. Studies concerning lncRNAs in biofluids as a potential biomarkers of renal cell carcinoma.

\begin{tabular}{|c|c|c|c|c|c|c|c|c|c|c|}
\hline Reference & Sample Size & Sample & RNA Isolation & $\begin{array}{l}\text { Biomarker } \\
\text { Selection }\end{array}$ & $\begin{array}{c}\text { Method } \\
\text { (Reference) }\end{array}$ & $\begin{array}{l}\text { Biomarker } \\
\text { Studied, } \\
\text { Regulation }\end{array}$ & AUC & DS (\%) & DSp (\%) & $\begin{array}{l}\text { Type of } \\
\text { Marker }\end{array}$ \\
\hline $\begin{array}{l}\text { Wu et al., } 2016 \\
\text { [119] }\end{array}$ & $\begin{array}{l}\text { Training set: } 24 \mathrm{ccRCC}+27 \mathrm{HC} \\
\text { Testing set\#1: } 37 \mathrm{ccRCC}+35 \mathrm{HC} \text {; } \\
\text { Testing set\#2: } 10 \mathrm{ccRCC}+8 \mathrm{BRT}\end{array}$ & Serum & $\begin{array}{l}\text { Blood Total } \\
\text { RNAIsolation Kit } \\
\text { (BioTeke) }\end{array}$ & $\begin{array}{l}\text { lncRNA Database } \\
\text { (82 lncRNA related } \\
\text { to the cancer) }\end{array}$ & $\begin{array}{c}\text { qRT-PCR } \\
\text { (Takara) ( } \beta \text {-actin) }\end{array}$ & $\begin{array}{c}\text { lncRNA-LET } \downarrow \\
\text { PVT1 } \downarrow \\
\text { PANDAR } \downarrow \\
\text { PTEMP1 } \downarrow \\
\text { LINC00963 } \downarrow \\
\text { Panel of } 5 \text { lncRNA }\end{array}$ & $\begin{array}{c}\text { na } \\
\text { na } \\
\text { na } \\
\text { na } \\
\text { na } \\
0.90 / 0.82\end{array}$ & $\begin{array}{c}\text { na } \\
\text { na } \\
\text { na } \\
\text { na } \\
\text { na } \\
79.2 / 67.6\end{array}$ & $\begin{array}{c}\text { na } \\
\text { na } \\
\text { na } \\
\text { na } \\
\text { na } \\
88.9 / 91.4\end{array}$ & $\mathrm{Dg}$ \\
\hline $\begin{array}{l}\text { Qu et al., } 2016 \\
\text { [110] }\end{array}$ & 71 RCC (ns) & Plasma & $\begin{array}{l}\text { mirVana PARIS } \\
\text { Kit (Ambion) }\end{array}$ & $\begin{array}{c}\operatorname{lncRNA}+ \\
\text { mRNAmicroarrays } \\
\text { (Agilent) }\end{array}$ & $\begin{array}{c}\text { qRT-PCR } \\
\text { (Takara) }(\beta \text {-actin) }\end{array}$ & lncARSR & na & na & na & $\mathrm{Pg}$ \\
\hline $\begin{array}{l}\text { He et al., } 2018 \\
\text { [121] }\end{array}$ & $46 \mathrm{RCC}(\mathrm{ns})+46 \mathrm{HC}$ & Serum & $\begin{array}{l}\text { TRIzol Reagent } \\
\text { (Invitrogen) }\end{array}$ & From literature & $\begin{array}{c}\text { qRT-PCR } \\
\text { (Takara) }(\beta \text {-actin) }\end{array}$ & GIHCG $\uparrow$ & 0.92 & 87.0 & 84.8 & $\mathrm{Dg}$ \\
\hline $\begin{array}{l}\text { Xie et al., } 2020 \\
{[122]}\end{array}$ & $114 \mathrm{RCC}(\mathrm{ns})+79 \mathrm{HC}$ & Serum & $\begin{array}{l}\text { TRIzol LS } \\
\text { (Invitrogen) }\end{array}$ & $\begin{array}{l}\text { From GEPIA } \\
\text { database }\end{array}$ & $\begin{array}{c}\text { qRT-PCR } \\
\text { (Qiagen) } \\
\text { (Cel-miR-39) }\end{array}$ & LINC00887 $\uparrow$ & 0.80 & 67.1 & 89.9 & $\mathrm{Dg} / \mathrm{Pg}$ \\
\hline $\begin{array}{l}\text { Zhang et al., } \\
2020[118]\end{array}$ & $\begin{array}{l}\text { Discovery set: } 5 \text { ccRCC }+5 \mathrm{HC} \text {; } \\
\text { Validation set: } 24 \mathrm{ccRCC}\end{array}$ & Plasma & $\begin{array}{c}\text { TRIzol } \\
\text { (Invitrogen) }\end{array}$ & $\begin{array}{c}\text { Arraystar lncRNA } \\
\text { microarrays } \\
\text { (KangChen } \\
\text { Biotech) }\end{array}$ & $\begin{array}{c}\text { qRT-PCR } \\
\text { (Nuoweizan } \\
\text { Biotech) }(\beta \text {-actin) }\end{array}$ & SOCS2-AS1 $\downarrow$ & na & na & na & na \\
\hline
\end{tabular}

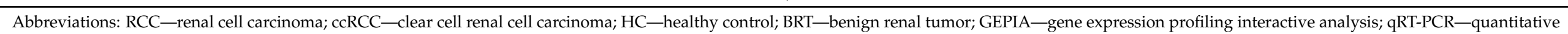

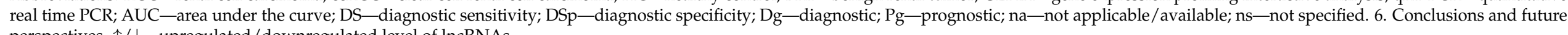
perspectives. $\uparrow / \downarrow$-upregulated/downregulated level of lncRNAs. 
As in the case of miRNAs, the understanding of the biological function of particular lncRNAs is crucial to transfer them to the clinic as a molecular test. The biological basis of lncRNAs in the case of renal cancer was investigated in the three studies [110,121,122]. He et al. [121] and Xie et al. [122] revealed that GIHCG and LINC00887 promoted RCC cells proliferation and migration, and thus may be related to tumor progression; however, the exact molecular pathway remained unclear. The mechanism of action of examined lncRNA was most comprehensively described by Qu et al. [110]. The authors observed that lncARSR served as a sponge, sequestering miR-34 and miR-449, leading to the upregulation of their target receptor tyrosine kinase AXL/c-MET, which in turn activated STAT3, AKT, and ERK signaling pathways, resulting in sunitinib resistance in the RCC cells. Moreover, activated AKT further promoted lncARSR expression by suppressing the transcription factors FOXO1 and FOXO3A, acting as transcription repressors, by recruiting a histone deacetylase. The researches also revealed that lncARSR secretion, from the sunitinibresistant RCC cells via exosomes, disseminates drug resistance to the sunitinib-sensitive cells. Thus, the results showed that lncARSR may act not only as a clinical biomarker for the monitoring of patients receiving the sunitinib, but also could serve as a therapeutic target to overcome sunitinib resistance in RCC patients.

Despite the described potential, all reported lncRNAs were investigated in a single study, most of which used a small set of samples with an unspecified particular subtype of cancer analyzed (Table 3). However, the specificity of lncRNAs to RCC is seemingly higher when compared to miRNAs or DNA methylation. Thus, lncRNAs appear to have potential as promising, well-performing novel RCC biomarkers.

\section{Other Epigenetic Phenomena for Non-Invasive Cancer Detection}

Another epigenetic phenomenon, such as circulating nucleosomes and their modifications as well as other non-coding RNAs, like P-Element induced wimpy testis (PIWI)interacting RNAs (piRNAs), may also serve as non-invasive biomarkers for cancers [123,124], while other ncRNAs are far less appropriate as reviewed previously [125].

PiRNA refers to a group of non-coding RNAs, 26-31 nucleotides in length, that maintain genomic stability by silencing transposable elements through $\mathrm{CpG}$ methylation, chromatin remodeling, and repression of complementary mRNAs [126]. Recently, it was observed that piRNAs may play an important role in carcinogenesis by driving the inhibition or degradation of oncogenes or tumor suppressor genes, respectively, and the deregulation of various piRNAs was observed in RCC $[127,128]$. There are two studies on circulating piRNAs in the serum and urine samples of RCC patients $[129,130]$. Iliev et al. [129] observed a significantly higher level of piR-823 in the serum $(n=178)$ of RCC patients when compared to the healthy controls $(n=101)$, but the diagnostic performance was low with an AUC $=0.63$. The better diagnostic potential, with an AUC $=0.74$, was established in the urine samples; however, only 20 RCC and 15 healthy control samples were investigated. Meanwhile, Zhao et al. [130] detected downregulated levels of piR-34536 and piR-51810 in ccRCC tissues as compared to normal renal samples, but no significant differences were observed in the serum of ccRCC patients $(n=30)$ in comparison to healthy individuals $(n=15)$. Thus, piRNAs may be promising novel circulating biomarkers of RCC; however, studies on the subject remain quite limited.

Histone modifications mostly include acetylation and methylation of lysine residues, and commonly lead to nearby gene transcriptional activation or repression, respectively, by regulating the access of transcriptional factors to DNA [131]. Deregulation of histone modifications is often involved in tumorigenesis and may also be used as disease biomarkers with the ability to detect such alterations in the biofluids [132,133]. Although utilization of circulating nucleosomes in combination with conventional biomarkers of some cancer types may increase specificity and sensitivity of current tests, as reviewed previously [123], to the best of our knowledge no such investigations were conducted in the field of renal cell carcinoma. 


\section{Conclusions and Future Perspectives}

Over the course of almost two decades worth of reports, a considerable number of circulating epigenetic biomarkers of RCC were suggested as possible diagnostic and prognostic tools (Figure 1); however, no marker has reached the clinic yet. The development of a biomarker assay for clinical practice is a multistage process requiring a vast number of samples and validation steps. The majority of the studies conducted thus far, however, lacked internal validation, used relatively small and heterogeneous cohorts, and a minimal number of biomarkers (out of $>100$ studied) were investigated in more than one study. Most of the studies focused primarily on the diagnostic potential of the particular biomarkers, whereas investigations on the prognostic potential were relatively rare. Moreover, analytical issues, including accuracy, sensitivity, and specificity, were not sufficiently studied and need to be addressed. Thus far, investigators commonly used blood samples (serum/plasma) as a source of nucleic acids, while urine, as a convenient liquid biopsy source for urological cancers, still requires further exploration. Moreover, miRNAs were the most widely studied in terms of potential non-invasive biomarkers for RCC, while, despite their higher stability and earlier occurrence, a limited number of studies focused on DNA methylation. In addition, due to the high specificity and diagnostic potential of lncRNA, further efforts should be made for the wider investigation of these novel biomarkers in the future. Finally, although numerous novel candidate biomarkers were produced, the studies of their biological functions in RCC are scarce; therefore, more detailed insights into their potential mechanism of action in RCC cells are also desirable. Thus, considering renal cancer has the highest mortality rate of all urinary system neoplasms, there is a considerable demand to validate the existing potential biomarkers, and elucidate their biological functions, alongside continuing the search for novel biomarkers with better performance.

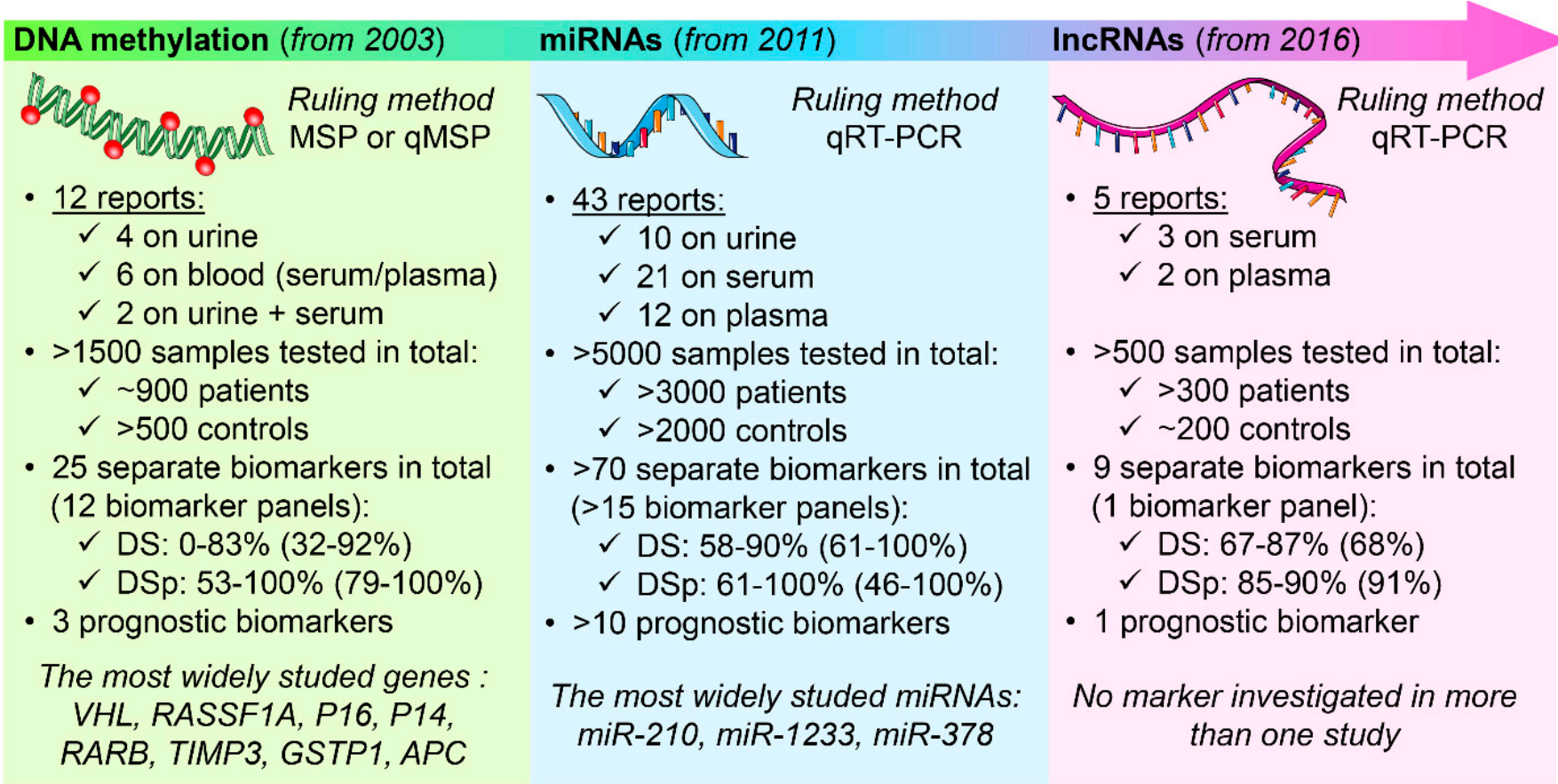

Figure 1. A summary of investigations conducted to date on biofluid circulating epigenetic biomarkers for RCC. This table was created using images from Servier Medical Art Commons Attribution 3.0 Unported License (http:/ / smart.servier.com, accessed on 3 May 2021). Servier Medical Art by Servier is licensed under a Creative Commons Attribution 3.0 Unported License. Abbreviations: DS—diagnostic sensitivity; DSp—diagnostic specificity. 
Large-scale studies addressing specific DNA methylation, miRNA, or lncRNA patterns in the bodily fluids of patients with RCC are urgently needed for novel biomarker discovery. Next-generation sequencing could be a valuable tool for the rapid screening of liquid biopsy samples in multicenter cohort studies. Moreover, NGS and digital PCR might be more accurate and sensitive than conventional prevailing methods (PCR or qPCR) for the validation of discovered biomarkers. Ultimately, multimarker panels seem to be more informative compared to individual ones and need to be more thoroughly addressed in the future.

Funding: This study was funded by the Research Council of Lithuania (Grant No. S-MIP-17-54).

Institutional Review Board Statement: Not applicable.

Informed Consent Statement: Not applicable.

Data Availability Statement: Not applicable.

Conflicts of Interest: The authors declare no competing interest.

\section{References}

1. Siegel, R.L.; Miller, K.D.; Jemal, A. Cancer statistics, 2015. CA Cancer J. Clin. 2015, 65, 5-29. [CrossRef]

2. Chow, W.H.; Dong, L.M.; Devesa, S.S. Epidemiology and risk factors for kidney cancer. Nat. Rev. Urol. 2010, 7, 245-257. [CrossRef]

3. Hsieh, J.J.; Purdue, M.P.; Signoretti, S.; Swanton, C.; Albiges, L.; Schmidinger, M.; Heng, D.Y.; Larkin, J.; Ficarra, V. Renal cell carcinoma. Nat. Rev. Dis. Prim. 2017, 3, 17009. [CrossRef]

4. Dabestani, S.; Thorstenson, A.; Lindblad, P.; Harmenberg, U.; Ljungberg, B.; Lundstam, S. Renal cell carcinoma recurrences and metastases in primary non-metastatic patients: A population-based study. World J. Urol. 2016, 34, 1081-1086. [CrossRef] [PubMed]

5. Novara, G.; Ficarra, V.; Antonelli, A.; Artibani, W.; Bertini, R.; Carini, M.; Cosciani Cunico, S.; Imbimbo, C.; Longo, N.; Martignoni, G.; et al. SATURN Project-LUNA Foundation. Validation of the 2009 TNM version in a large multi-institutional cohort of patients treated for renal cell carcinoma: Are further improvements needed? Eur. Urol. 2010, 58, 588-595. [CrossRef] [PubMed]

6. Jayson, M.; Sanders, H. Increased incidence of serendipitously discovered renal cell carcinoma. Urology 1998, 51, 203-205. [CrossRef]

7. Mitchell, T.J.; Turajlic, S.; Rowan, A.; Nicol, D.; Farmery, J.H.R.; O’Brien, T.; Martincorena, I.; Tarpey, P.; Angelopoulos, N.; Yates, L.R.; et al. Timing the landmark events in the evolution of clear cell renal cell cancer: TRACERx renal. Cell 2018, 173, 611-623. [CrossRef]

8. Turajlic, S.; Xu, H.; Litchfield, K.; Rowan, A.; Chambers, T.; Lopez, J.I.; Nicol, D.; O’Brien, T.; Larkin, J.; Horswell, S.; et al. Tracking cancer evolution reveals constrained routes to metastases: TRACERx renal. Cell 2018, 173, 581-594. [CrossRef]

9. Turajlic, S.; Xu, H.; Litchfield, K.; Rowan, A.; Horswell, S.; Chambers, T.; O’Brien, T.; Lopez, J.I.; Watkins, T.B.K.; Nicol, D.; et al. Deterministic evolutionary trajectories influence primary tumor growth: TRACERx renal. Cell 2018, 173, 595-610. [CrossRef]

10. Gerlinger, M.; Horswell, S.; Larkin, J.; Rowan, A.J.; Salm, M.P.; Varela, I.; Fisher, R.; McGranahan, N.; Matthews, N.; Santos, C.R.; et al. Genomic architecture and evolution of clear cell renal cell carcinomas defined by multiregion sequencing. Nat. Genet. 2014, 46, 225-233. [CrossRef]

11. Arai, E.; Kanai, Y. Genetic and epigenetic alterations during renal carcinogenesis. Int. J. Clin. Exp. Pathol. 2010, 4, 58-73.

12. Chen, W.; Zhuang, J.; Wang, P.P.; Jiang, J.; Lin, C.; Zeng, P.; Liang, Y.; Zhang, X.; Dai, Y.; Diao, H. DNA methylation-based classification and identification of renal cell carcinoma prognosis-subgroups. Cancer Cell Int. 2019, 19, 185. [CrossRef] [PubMed]

13. Dessie, E.Y.; Tsai, J.J.P.; Chang, J.G.; Ng, K.L. A novel miRNA-based classification model of risks and stages for clear cell renal cell carcinoma patients. BMC Bioinform. 2021, 22 (Suppl. 10), 270. [CrossRef]

14. Sun, Z.; Jing, C.; Xiao, C.; Li, T. Long Non-Coding RNA Profile Study Identifies an Immune-Related lncRNA Prognostic Signature for Kidney Renal Clear Cell Carcinoma. Front. Oncol. 2020, 10, 1430. [CrossRef] [PubMed]

15. Ricketts, C.J.; De Cubas, A.A.; Fan, H.; Smith, C.C.; Lang, M.; Reznik, E.; Bowlby, R.; Gibb, E.A.; Akbani, R.; Beroukhim, R.; et al. The Cancer Genome Atlas Comprehensive Molecular Characterization of Renal Cell Carcinoma. Cell Rep. 2018, 23, 313-326.e5. [CrossRef]

16. Koch, A.; Joosten, S.C.; Feng, Z.; de Ruijter, T.C.; Draht, M.X.; Melotte, V.; Smits, K.M.; Veeck, J.; Herman, J.G.; Van Neste, L.; et al. Analysis of DNA methylation in cancer: Location revisited. Nat. Rev. Clin. Oncol. 2018, 15, 459-466. [CrossRef] [PubMed]

17. Larsen, L.K.; Lind, G.E.; Guldberg, P.; Dahl, C. DNA-Methylation-Based Detection of Urological Cancer in Urine: Overview of Biomarkers and Considerations on Biomarker Design, Source of DNA, and Detection Technologies. Int. J. Mol. Sci. 2019, 20, 2657. [CrossRef] [PubMed]

18. Fendler, A.; Stephan, C.; Yousef, G.M.; Kristiansen, G.; Jung, K. The translational potential of microRNAs as biofluid markers of urological tumours. Nat. Rev. Urol. 2016, 13, 734-752. [CrossRef] [PubMed] 
19. Stirzaker, C.; Taberlay, P.C.; Statham, A.L.; Clark, S.J. Mining cancer methylomes: Prospects and challenges. Trends Genet. 2014, 30, 75-84. [CrossRef]

20. Lasseigne, B.N.; Brooks, J.D. The role of DNA methylation in renal cell carcinoma. Mol. Diagn. Ther. 2018, 22, 431-442. [CrossRef]

21. Minardi, D.; Lucarini, G.; Filosa, A.; Milanese, G.; Zizzi, A.; Di Primio, R.; Montironi, R.; Muzzonigro, G. Prognostic role of global DNA-methylation and histone acetylation in pT1a clear cell renal carcinoma in partial nephrectomy specimens. J. Cell Mol. Med. 2009, 13, 2115-2121. [CrossRef] [PubMed]

22. Cancer Genome Atlas Research Network. Comprehensive molecular characterization of clear cell renal cell carcinoma. Nature 2013, 499, 43-49. [CrossRef] [PubMed]

23. Morris, M.R.; Maher, E.R. Epigenetics of renal cell carcinoma: The path towards new diagnostics and therapeutics. Genome Med. 2010, 2, 59. [CrossRef] [PubMed]

24. Battagli, C.; Uzzo, R.G.; Dulaimi, E.; Ibanez de Caceres, I.; Krassenstein, R.; Al-Saleem, T.; Greenberg, R.E.; Cairns, P. Promoter hypermethylation of tumor suppressor genes in urine from kidney cancer patients. Cancer Res. 2003, 63, 8695-8699. [PubMed]

25. Hoque, M.O.; Begum, S.; Topaloglu, O.; Jeronimo, C.; Mambo, E.; Westra, W.H.; Califano, J.A.; Sidransky, D. Quantitative detection of promoter hypermethylation of multiple genes in the tumor, urine, and serum DNA of patients with renal cancer. Cancer Res. 2004, 64, 5511-5517. [CrossRef]

26. Urakami, S.; Shiina, H.; Enokida, H.; Hirata, H.; Kawamoto, K.; Kawakami, T.; Kikuno, N.; Tanaka, Y.; Majid, S.; Nakagawa, M.; et al. Wnt antagonist family genes as biomarkers for diagnosis, staging, and prognosis of renal cell carcinoma using tumor and serum DNA. Clin. Cancer Res. 2006, 12, 6989-6997. [CrossRef] [PubMed]

27. Costa, V.L.; Henrique, R.; Danielsen, S.A.; Eknaes, M.; Patrício, P.; Morais, A.; Oliveira, J.; Lothe, R.A.; Teixeira, M.R.; Lind, G.E.; et al. TCF21 and PCDH17 methylation: An innovative panel of biomarkers for a simultaneous detection of urological cancers. Epigenetics 2011, 6, 1120-1130. [CrossRef]

28. de Martino, M.; Klatte, T.; Haitel, A.; Marberger, M. Serum cell-free DNA in renal cell carcinoma: A diagnostic and prognostic marker. Cancer 2012, 118, 82-90. [CrossRef] [PubMed]

29. Hauser, S.; Zahalka, T.; Fechner, G.; Müller, S.C.; Ellinger, J. Serum DNA hypermethylation in patients with kidney cancer: Results of a prospective study. Anticancer Res. 2013, 33, 4651-4656.

30. Xin, J.; Xu, R.; Lin, S.; Xin, M.; Cai, W.; Zhou, J.; Fu, C.; Zhen, G.; Lai, J.; Li, Y.; et al. Clinical potential of TCF21 methylation in the diagnosis of renal cell carcinoma. Oncol. Lett. 2016, 12, 1265-1270. [CrossRef]

31. Skrypkina, I.; Tsyba, L.; Onyshchenko, K.; Morderer, D.; Kashparova, O.; Nikolaienko, O.; Panasenko, G.; Vozianov, S.; Romanenko, A.; Rynditch, A. Concentration and Methylation of Cell-Free DNA from Blood Plasma as Diagnostic Markers of Renal Cancer. Dis. Markers 2016, 2016, 3693096. [CrossRef]

32. Lin, Y.L.; Wang, Y.P.; Li, H.Z.; Zhang, X. Aberrant Promoter Methylation of PCDH17 (Protocadherin 17) in Serum and its Clinical Significance in Renal Cell Carcinoma. Med. Sci. Monit. 2017, 23, 3318-3323. [CrossRef]

33. Jung, M.; Ellinger, J.; Gevensleben, H.; Syring, I.; Lüders, C.; de Vos, L.; Pützer, S.; Bootz, F.; Landsberg, J.; Kristiansen, G.; et al Cell-Free SHOX2 DNA Methylation in Blood as a Molecular Staging Parameter for Risk Stratification in Renal Cell Carcinoma Patients: A Prospective Observational Cohort Study. Clin. Chem. 2019, 65, 559-568. [CrossRef] [PubMed]

34. Outeiro-Pinho, G.; Barros-Silva, D.; Aznar, E.; Sousa, A.I.; Vieira-Coimbra, M.; Oliveira, J.; Gonçalves, C.S.; Costa, B.M.; Junker, K.; Henrique, R.; et al. MicroRNA-30a-5p(me): A novel diagnostic and prognostic biomarker for clear cell renal cell carcinoma in tissue and urine samples. J. Exp. Clin. Cancer Res. 2020, 39, 98. [CrossRef]

35. Nuzzo, P.V.; Berchuck, J.E.; Korthauer, K.; Spisak, S.; Nassar, A.H.; Abou Alaiwi, S.; Chakravarthy, A.; Shen, S.Y.; Bakouny, Z.; Boccardo, F.; et al. Detection of renal cell carcinoma using plasma and urine cell-free DNA methylomes. Nat. Med. 2020, 26, 1041-1043. [CrossRef] [PubMed]

36. Lommen, K.; Vaes, N.; Aarts, M.J.; van Roermund, J.G.; Schouten, L.J.; Oosterwijk, E.; Melotte, V.; Tjan-Heijnen, V.C.; van Engeland, M.; Smits, K.M. Diagnostic DNA Methylation Biomarkers for Renal Cell Carcinoma: A Systematic Review. Eur. Urol. Oncol. 2021, 4, 215-226. [CrossRef]

37. Nilsen, T.W. Mechanisms of microRNA-mediated gene regulation in animal cells. Trends Genet. 2007, 23, 243-249. [CrossRef] [PubMed]

38. Pillai, R.S.; Bhattacharyya, S.N.; Filipowicz, W. Repression of protein synthesis by miRNAs: How many mechanisms? Trends Cell Biol. 2007, 17, 118-126. [CrossRef]

39. Fang, L.; Deng, Z.; Shatseva, T.; Yang, J.; Peng, C.; Du, W.W.; Yee, A.J.; Ang, L.C.; He, C.; Shan, S.W.; et al. MicroRNA miR-93 promotes tumor growth and angiogenesis by targeting integrin-beta8. Oncogene 2011, 30, 806-821. [CrossRef] [PubMed]

40. Chen, X.; Xu, X.; Pan, B.; Zeng, K.; Xu, M.; Liu, X.; He, B.; Pan, Y.; Sun, H.; Wang, S. miR-150-5p suppresses tumor progression by targeting VEGFA in colorectal cancer. Aging 2018, 10, 3421-3437. [CrossRef]

41. Sun, X.; Dai, G.; Yu, L.; Hu, Q.; Chen, J.; Guo, W. miR-143-3p inhibits the proliferation, migration and invasion in osteosarcoma by targeting FOSL2. Sci. Rep. 2018, 8, 606. [CrossRef]

42. Xiao, W.; Wang, X.; Wang, T.; Xing, J. MiR-223-3p promotes cell proliferation and metastasis by downregulating SLC4A4 in clear cell renal cell carcinoma. Aging 2019, 11, 615-633. [CrossRef]

43. Jia, Y.J.; Liu, Z.B.; Wang, W.G.; Sun, C.B.; Wei, P.; Yang, Y.L.; You, M.J.; Yu, B.H.; Li, X.Q.; Zhou, X.Y. HDAC6 regulates microRNA$27 \mathrm{~b}$ that suppresses proliferation, promotes apoptosis and target MET in diffuse large B-cell lymphoma. Leukemia 2018, 32, 703-711. [CrossRef] 
44. Sharifi, M.; Moridnia, A. Apoptosis-inducing and antiproliferative effect by inhibition of miR-182 $5 p$ through the regulation of CASP9 expression in human breast cancer. Cancer Gene Ther. 2017, 24, 75-82. [CrossRef]

45. Fan, Y.; Ma, X.; Li, H.; Gao, Y.; Huang, Q.; Zhang, Y.; Bao, X.; Du, Q.; Luo, G.; Liu, K.; et al. miR-122 promotes metastasis of clear-cell renal cell carcinoma by downregulating Dicer. Int. J. Cancer 2018, 142, 547-560. [CrossRef]

46. Xiao, W.; Lou, N.; Ruan, H.; Bao, L.; Xiong, Z.; Yuan, C.; Tong, J.; Xu, G.; Zhou, Y.; Qu, Y.; et al. Mir-144-3p promotes cell proliferation, metastasis, sunitinib resistance in clear cell renal cell carcinoma by downregulating ARID1A. Cell. Physiol. Biochem. Int. J. Exp. Cell Phys. Biochem. Pharmacol. 2017, 43, 2420-2433. [CrossRef] [PubMed]

47. Kabir, T.D.; Ganda, C.; Brown, R.M.; Beveridge, D.J.; Richardson, K.L.; Chaturvedi, V.; Candy, P.; Epis, M.; Wintle, L.; Kalinowski, F.; et al. A microRNA-7/growth arrest specific 6/TYRO3 axis regulates the growth and invasiveness of sorafenib-resistant cells in human hepatocellular carcinoma. Hepatology 2018, 67, 216-231. [CrossRef]

48. Ma, J.; Dong, C.; Ji, C. MicroRNA and dru resistance. Cancer Gene. Ther. 2010, 17, 523-531. [CrossRef] [PubMed]

49. Schaefer, A.; Stephan, C.; Busch, J.; Yousef, G.M.; Jung, K. Diagnostic, prognostic and therapeutic implications of microRNAs in urologic tumors. Nat. Rev. Urol. 2010, 7, 286-297. [CrossRef]

50. Lichner, Z.; Saleh, C.; Subramaniam, V.; Seivwright, A.; Prud'homme, G.J.; Yousef, G.M. miR-17 inhibition enhances the formation of kidney cancer spheres with stem cell/tumor initiating cell properties. Oncotarget 2014, 6, 5567-5581. [CrossRef]

51. Weber, J.A.; Baxter, D.H.; Zhang, S.; Huang, D.Y.; Huang, K.H.; Lee, M.J.; Galas, D.J.; Wang, K. The microRNA spectrum in 12 body fluids. Clin. Chem. 2010, 56, 1733-1741. [CrossRef]

52. Arroyo, J.D.; Chevillet, J.R.; Kroh, E.M.; Ruf, I.K.; Pritchard, C.C.; Gibson, D.F.; Mitchell, P.S.; Bennett, C.F.; Pogosova-Agadjanyan, E.L.; Stirewalt, D.L.; et al. Argonaute 2 complexes carry a population of circulating microRNAs in dependent of vesicles in human plasma. Proc. Natl. Acad. Sci. USA 2011, 108, 5003-5008. [CrossRef] [PubMed]

53. Vickers, K.C.; Palmisano, B.T.; Shoucri, B.M.; Shamburek, R.D.; Remaley, A.T. MicroRNAs are transported in plasma and delivered to recipient cells by high density lipoproteins. Nat. Cell Biol. 2011, 13, 423-433. [CrossRef] [PubMed]

54. Iftikhar, H.; Carney, G.E. Evidence and potential in vivo functions for biofluid miRNAs: From expression profiling to functional testing: Potential roles of extracellular miRNAs as indicators of physiological change and as agents of intercellular information exchange. Bioessays 2016, 38, 367-378. [CrossRef]

55. Gallo, A.; Tandon, M.; Alevizos, I.; Illei, G.G. The majority of microRNAs detectable in serum and saliva is concentrated in exosomes. PLoS ONE 2012, 7, e30679. [CrossRef]

56. Chen, X.; Ba, Y.; Ma, L.; Cai, X.; Yin, Y.; Wang, K.; Guo, J.; Zhang, Y.; Chen, J.; Guo, X.; et al. Characterization of microRNAs in serum: A novel class of biomarkers for diagnosis of cancer and other diseases. Cell Res. 2008, 18, 997-1006. [CrossRef]

57. Hunter, M.P.; Ismail, N.; Zhang, X.; Aguda, B.D.; Lee, E.J.; Yu, L.; Xiao, T.; Schafer, J.; Lee, M.L.; Schmittgen, T.D.; et al. Detection of microRNA expression in human peripheral blood microvesicles. PLoS ONE 2008, 3, e3694. [CrossRef] [PubMed]

58. Wulfken, L.M.; Moritz, R.; Ohlmann, C.; Holdenrieder, S.; Jung, V.; Becker, F.; Herrmann, E.; Walgenbach-Brünagel, G.; von Ruecker, A.; Müller, S.C.; et al. MicroRNAs in renal cell carcinoma: Diagnostic implications of serum miR-1233 levels. PLoS ONE 2011, 6, e25787. [CrossRef]

59. Zhai, Q.; Zhou, L.; Zhao, C.; Wan, J.; Yu, Z.; Guo, X.; Qin, J.; Chen, J.; Lu, R. Identification of miR-508-3p and miR-509-3p that are associated with cell invasion and migration and involved in the apoptosis of renal cell carcinoma. Biochem. Biophys. Res. Commun. 2012, 419, 621-626. [CrossRef]

60. von Brandenstein, M.; Pandarakalam, J.J.; Kroon, L.; Loeser, H.; Herden, J.; Braun, G.; Wendland, K.; Dienes, H.P.; Engelmann, U.; Fries, J.W. MicroRNA 15a, inversely correlated to PKCalpha, is a potential marker to differentiate between benign and malignant renal tumors in biopsy and urine samples. Am. J. Pathol. 2012, 180, 1787-1797. [CrossRef]

61. Redova, M.; Poprach, A.; Nekvindova, J.; Iliev, R.; Radova, L.; Lakomy, R.; Svoboda, M.; Vyzula, R.; Slaby, O. Circulating miR-378 and miR-451 in serum are potential biomarkers for renal cell carcinoma. J. Transl. Med. 2012, 10, 55. [CrossRef]

62. Hauser, S.; Wulfken, L.M.; Holdenrieder, S.; Moritz, R.; Ohlmann, C.H.; Jung, V.; Becker, F.; Herrmann, E.; Walgenbach-Brünagel, G.; von Ruecker, A.; et al. Analysis of serum microRNAs (miR-26a-2*, miR-191, miR-337-3p and miR-378) as potential biomarkers in renal cell carcinoma. Cancer Epidemiol. 2012, 36, 391-394. [CrossRef]

63. Zhao, A.; Li, G.; Péoc'h, M.; Genin, C.; Gigante, M. Serum miR-210 as a novel biomarker for molecular diagnosis of clear cell renal cell carcinoma. Exp. Mol. Pathol. 2013, 94, 115-120. [CrossRef]

64. Cheng, T.; Wang, L.; Li, Y.; Huang, C.; Zeng, L.; Yang, J. Differential microRNA expression in renal cell carcinoma. Oncol. Lett. 2013, 6, 769-776. [CrossRef]

65. Zhao, J.; Lei, T.; Xu, C.; Li, H.; Ma, W.; Yang, Y.; Fan, S.; Liu, Y. MicroRNA-187, down-regulated in clear cell renal cell carcinoma and associated with lower survival, inhibits cell growth and migration though targeting B7-H3. Biochem. Biophys. Res. Commun. 2013, 438, 439-444. [CrossRef]

66. Iwamoto, H.; Kanda, Y.; Sejima, T.; Osaki, M.; Okada, F.; Takenaka, A. Serum miR-210 as a potential biomarker of early clear cell renal cell carcinoma. Int. J. Oncol. 2014, 44, 53-58. [CrossRef] [PubMed]

67. Teixeira, A.L.; Ferreira, M.; Silva, J.; Gomes, M.; Dias, F.; Santos, J.I.; Maurício, J.; Lobo, F.; Medeiros, R. Higher circulating expression levels of miR-221 associated with poor overall survival in renal cell carcinoma patients. Tumour. Biol. 2014, 35, 4057-4066. [CrossRef] [PubMed]

68. Wang, C.; Hu, J.; Lu, M.; Gu, H.; Zhou, X.; Chen, X.; Zen, K.; Zhang, C.Y.; Zhang, T.; Ge, J.; et al. A panel of five serum miRNAs as a potential diagnostic tool for early-stage renal cell carcinoma. Sci. Rep. 2015, 5, 7610. [CrossRef] [PubMed] 
69. Zhang, C.; Wang, Q.; Xi, X.; Jiao, J.; Xu, W.; Huang, J.; Lai, Z. High serum miR-183 level is associated with the bioactivity of macrophage derived from tuberculosis patients. Int. J. Clin. Exp. Pathol. 2015, 8, 655-659.

70. Fedorko, M.; Stanik, M.; Iliev, R.; Redova-Lojova, M.; Machackova, T.; Svoboda, M.; Pacik, D.; Dolezel, J.; Slaby, O. Combination of MiR-378 and MiR-210 Serum Levels Enables Sensitive Detection of Renal Cell Carcinoma. Int. J. Mol. Sci. 2015, 16, 23382-23389. [CrossRef]

71. Liu, T.Y.; Zhang, H.; Du, S.M.; Li, J.; Wen, X.H. Expression of microRNA-210 in tissue and serum of renal carcinoma patients and its effect on renal carcinoma cell proliferation, apoptosis, and invasion. Genet. Mol. Res. 2016, 15, 15017746. [CrossRef] [PubMed]

72. Zhang, W.; Ni, M.; Su, Y.; Wang, H.; Zhu, S.; Zhao, A.; Li, G. MicroRNAs in Serum Exosomes as Potential Biomarkers in Clear-cell Renal Cell Carcinoma. Eur. Urol. Focus. 2018, 4, 412-419. [CrossRef]

73. Tusong, H.; Maolakuerban, N.; Guan, J.; Rexiati, M.; Wang, W.G.; Azhati, B.; Nuerrula, Y.; Wang, Y.J. Functional analysis of serum microRNAs miR-21 and miR-106a in renal cell carcinoma. Cancer Biomark. 2017, 18, 79-85. [CrossRef]

74. Butz, H.; Nofech-Mozes, R.; Ding, Q.; Khella, H.W.Z.; Szabó, P.M.; Jewett, M.; Finelli, A.; Lee, J.; Ordon, M.; Stewart, R.; et al. Exosomal MicroRNAs Are Diagnostic Biomarkers and Can Mediate Cell-Cell Communication in Renal Cell Carcinoma. Eur. Urol. Focus. 2016, 2, 210-218. [CrossRef] [PubMed]

75. Li, G.; Zhao, A.; Péochm, M.; Cottier, M.; Mottet, N. Detection of urinary cell-free miR-210 as a potential tool of liquid biopsy for clear cell renal cell carcinoma. Urol. Oncol. 2017, 35, 294-299. [CrossRef] [PubMed]

76. Yadav, S.; Khandelwal, M.; Seth, A.; Saini, A.K.; Dogra, P.N.; Sharma, A. Serum microRNA Expression Profiling: Potential Diagnostic Implications of a Panel of Serum microRNAs for Clear Cell Renal Cell Cancer. Urology 2017, 104, 64-69. [CrossRef]

77. Chanudet, E.; Wozniak, M.B.; Bouaoun, L.; Byrnes, G.; Mukeriya, A.; Zaridze, D.; Brennan, P.; Muller, D.C.; Scelo, G. Large-scale genome-wide screening of circulating microRNAs in clear cell renal cell carcinoma reveals specific signatures in late-stage disease. Int. J. Cancer 2017, 141, 1730-1740. [CrossRef]

78. Du, M.; Giridhar, K.V.; Tian, Y.; Tschannen, M.R.; Zhu, J.; Huang, C.C.; Kilari, D.; Kohli, M.; Wang, L. Plasma exosomal miRNAs-based prognosis in metastatic kidney cancer. Oncotarget 2017, 8, 63703-63714. [CrossRef]

79. Lou, N.; Ruan, A.M.; Qiu, B.; Bao, L.; Xu, Y.C.; Zhao, Y.; Sun, R.L.; Zhang, S.T.; Xu, G.H.; Ruan, H.L.; et al. miR-144-3p as a novel plasma diagnostic biomarker for clear cell renal cell carcinoma. Urol. Oncol. 2017, 35, 36.e7-36.e14. [CrossRef]

80. Petrozza, V.; Pastore, A.L.; Palleschi, G.; Tito, C.; Porta, N.; Ricci, S.; Marigliano, C.; Costantini, M.; Simone, G.; Di Carlo, A.; et al. Secreted miR-210-3p as non-invasive biomarker in clear cell renal cell carcinoma. Oncotarget 2017, 8, 69551-69558. [CrossRef] [PubMed]

81. Fedorko, M.; Juracek, J.; Stanik, M.; Svoboda, M.; Poprach, A.; Buchler, T.; Pacik, D.; Dolezel, J.; Slaby, O. Detection of let-7 miRNAs in urine supernatant as potential diagnostic approach in non-metastatic clear-cell renal cell carcinoma. Biochem. Med. (Zagreb) 2017, 27, 411-417. [CrossRef]

82. Wang, Z.K.; Luo, L.; Du, Z.J.; Zhang, G.M.; Sun, L.J. MiR429 expression level in renal cell cancer and its correlation with the prognosis of patients. J. BUON 2017, 22, 1428-1433.

83. Dias, F.; Teixeira, A.L.; Ferreira, M.; Adem, B.; Bastos, N.; Vieira., J.; Fernandes, M.; Sequeira, M.I.; Maurício, J.; Lobo, F.; et al. Plasmatic miR-210, miR-221 and miR-1233 profile: Potential liquid biopsies candidates for renal cell carcinoma. Oncotarget 2017, 8, 103315-103326. [CrossRef]

84. Li, M.; Sha, Y.; Zhang, X. MiR-22 functions as a biomarker and regulates cell proliferation, cycle, apoptosis, migration and invasion in renal cell carcinoma. Int. J. Clin. Exp. Pathol. 2017, 10, 11425-11437.

85. Heinemann, F.G.; Tolkach, Y.; Deng, M.; Schmidt, D.; Perner, S.; Kristiansen, G.; Müller, S.C.; Ellinger, J. Serum miR-122-5p and miR-206 expression: Non-invasive prognostic biomarkers for renal cell carcinoma. Clin. Epigenet. 2018, 10, 11. [CrossRef]

86. Mytsyk, Y.; Dosenko, V.; Borys, Y.; Kucher, A.; Gazdikova, K.; Busselberg, D.; Caprnda, M.; Kruzliak, P.; Farooqi, A.A.; Lubov, M. MicroRNA-15a expression measured in urine samples as a potential biomarker of renal cell carcinoma. Int. Urol. Nephrol. 2018, 50, 851-859. [CrossRef]

87. Chen, X.; Lou, N.; Ruan, A.; Qiu, B.; Yan, Y.; Wang, X.; Du, Q.; Ruan, H.; Han, W.; Wei, H.; et al. miR-224/miR-141 ratio as a novel diagnostic biomarker in renal cell carcinoma. Oncol. Lett. 2018, 16, 1666-1674. [CrossRef]

88. Wang, X.; Wang, T.; Chen, C.; Wu, Z.; Bai, P.; Li, S.; Chen, B.; Liu, R.; Zhang, K.; Li, W.; et al. Serum exosomal miR-210 as a potential biomarker for clear cell renal cell carcinoma. J. Cell Biochem. 2019, 120, 1492-1502. [CrossRef]

89. Song, S.; Long, M.; Yu, G.; Cheng, Y.; Yang, Q.; Liu, J.; Wang, Y.; Sheng, J.; Wang, L.; Wang, Z.; et al. Urinary exosome miR-30c-5p as a biomarker of clear cell renal cell carcinoma that inhibits progression by targeting HSPA5. J. Cell Mol. Med. 2019, 23, 6755-6765. [CrossRef] [PubMed]

90. Liu, S.; Deng, X.; Zhang, J. Identification of dysregulated serum miR-508-3p and miR-885-5p as potential diagnostic biomarkers of clear cell renal carcinoma. Mol. Med. Rep. 2019, 20, 5075-5083. [CrossRef]

91. Zhao, L.; Liu, K.; Pan, X.; Quan, J.; Zhou, L.; Li, Z.; Lin, C.; Xu, J.; Xu, W.; Guan, X.; et al. miR-625-3p promotes migration and invasion and reduces apoptosis of clear cell renal cell carcinoma. Am. J. Transl. Res. 2019, 11, 6475-6486.

92. Petrozza, V.; Costantini, M.; Tito, C.; Giammusso, L.M.; Sorrentino, V.; Cacciotti, J.; Porta, N.; Iaiza, A.; Pastore, A.L.; Di Carlo, A.; et al. Emerging role of secreted miR-210-3p as potential biomarker for clear cell Renal Cell Carcinoma metastasis. Cancer Biomark. 2020, 27, 181-188. [CrossRef]

93. Di Meo, A.; Brown, M.D.; Finelli, A.; Jewett, M.A.S.; Diamandis, E.P.; Yousef, G.M. Prognostic urinary miRNAs for the assessment of small renal masses. Clin. Biochem. 2020, 75, 15-22. [CrossRef] 
94. Xiao, W.; Wang, C.; Chen, K.; Wang, T.; Xing, J.; Zhang, X.; Wang, X. MiR-765 functions as a tumour suppressor and eliminates lipids in clear cell renal cell carcinoma by downregulating PLP2. EBioMedicine 2020, 51, 102622. [CrossRef]

95. Kalogirou, C.; Ellinger, J.; Kristiansen, G.; Hatzichristodoulou, G.; Kübler, H.; Kneitz, B.; Busch, J.; Fendler, A. Identification of miR-21-5p and miR-210-3p serum levels as biomarkers for patients with papillary renal cell carcinoma: A multicenter analysis. Transl. Androl. Urol. 2020, 9, 1314-1322. [CrossRef]

96. Dias, F.; Teixeira, A.L.; Nogueira, I.; Morais, M.; Maia, J.; Bodo, C.; Ferreira, M.; Silva, A.; Vilhena, M.; Lobo, J.; et al. Extracellular Vesicles Enriched in hsa-miR-301a-3p and hsa-miR-1293 Dynamics in Clear Cell Renal Cell Carcinoma Patients: Potential Biomarkers of Metastatic Disease. Cancers 2020, 12, 1450. [CrossRef] [PubMed]

97. Wang, X.G.; Zhu, Y.W.; Wang, T.; Chen, B.; Xing, J.C.; Xiao, W. MiR-483-5p downregulation contributed to cell proliferation, metastasis, and inflammation of clear cell renal cell carcinoma. Kaohsiung J. Med. Sci. 2021, 37, 192-199. [CrossRef]

98. Huang, G.; Li, X.; Chen, Z.; Wang, J.; Zhang, C.; Chen, X.; Peng, X.; Liu, K.; Zhao, L.; Lai, Y.; et al. A Three-microRNA Panel in Serum: Serving as a Potential Diagnostic Biomarker for Renal Cell Carcinoma. Pathol. Oncol. Res. 2020, 26, 2425-2434. [CrossRef]

99. Xiao, C.T.; Lai, W.J.; Zhu, W.A.; Wang, H. MicroRNA Derived from Circulating Exosomes as Noninvasive Biomarkers for Diagnosing Renal Cell Carcinoma. Oncol. Targets Ther. 2020, 13, 10765-10774. [CrossRef]

100. Cochetti, G.; Cari, L.; Nocentini, G.; Maulà, V.; Suvieri, C.; Cagnani, R.; De Vermandois, J.A.R.; Mearini, E. Detection of urinary miRNAs for diagnosis of clear cell renal cell carcinoma. Sci. Rep. 2020, 10, 21290. [CrossRef]

101. Wang, K.; Yuan, Y.; Cho, J.H.; McClarty, S.; Baxter, D.; Galas, D.J. Comparing the microRNA spectrum between serum and plasma. PLoS ONE 2012, 7, e41561. [CrossRef] [PubMed]

102. Sanders, I.; Holdenrieder, S.; Walgenbach-Brunagel, G.; von Ruecker, A.; Kristiansen, G.; Müller, S.C.; Ellinger, J. Evaluation of reference genes for the analysis of serum miRNA in patients with prostate cancer, bladder cancer and renal cell carcinoma. Int. J. Urol. 2012, 19, 1017-1025. [CrossRef]

103. Fasanaro, P.; Greco, S.; Lorenzi, M.; Pescatori, M.; Brioschi, M.; Kulshreshtha, R.; Banfi, C.; Stubbs, A.; Calin, G.A.; Ivan, M.; et al. An integrated approach for experimental target identification of hypoxia-induced miR-210. J. Biol. Chem. 2009, 284, 35134-35143. [CrossRef]

104. Lu, J.; Xie, F.; Geng, L.; Shen, W.; Sui, C.; Yang, J. Potential role of MicroRNA-210 as biomarker in human cancers detection: A meta-analysis. Biomed. Res. Int. 2015, 303987, 2015. [CrossRef] [PubMed]

105. Yu, F.; Yang, J.; Ouyang, J.; Zheng, Y.; Chen, B.; Li, G.; Lu, Z.; Dong, P.; Zheng, J. Serum microRNA-210 levels in different groups of chronic hepatitis B patients. Clin. Chim. Acta 2015, 450, 203-209. [CrossRef] [PubMed]

106. Signorelli, S.S.; Li Volsi, G.; Pitruzzella, A.; Fiore, V.; Mangiafico, M.; Vanella, L.; Parenti, R.; Rizzo, M.; Volti, G.L. Circulating miR-130a, miR-27b, and miR-210 in patients with peripheral artery disease and their potential relationship with oxidative stress: A pilot study. Angiology 2016, 67, 945-950. [CrossRef]

107. Zhang, G.J.; Zhou, H.; Xiao, H.X.; Li, Y.; Zhou, T. MiR-378 is an independent prognostic factor and inhibits cell growth and invasion in colorectal cancer. BMC Cancer 2014, 214, 1-9. [CrossRef]

108. Yu, B.L.; Peng, X.H.; Zhao, F.P.; Liu, X.; Lu, J.; Wang, L.; Li, G.; Chen, H.H.; Li, X.P. MicroRNA-378 functions as an onco-miR in nasopharyngeal carcinoma by repressing TOB2 expression. Int. J. Oncol. 2014, 44, 1215-1222. [CrossRef]

109. Peng, W.X.; Koirala, P.; Mo, Y.Y. LncRNAmediated regulation of cell signaling in cancer. Oncogene 2017, 36, 5661-5667. [CrossRef]

110. Qu, L.; Ding, J.; Chen, C.; Wu, Z.J.; Liu, B.; Gao, Y.; Chen, W.; Liu, F.; Sun, W.; Li, X.F.; et al. Exosome-Transmitted lncARSR Promotes Sunitinib Resistance in Renal Cancer by Acting as a Competing Endogenous RNA. Cancer Cell 2016, $29,653-668$. [CrossRef]

111. Bhan, A.; Soleimani, M.; Mandal, S.S. Long noncoding RNA and cancer: A new paradigm. Cancer Res. 2017, 77, 3965-3981. [CrossRef]

112. Liu, X.; Hao, Y.; Yu, W.; Yang, X.; Luo, X.; Zhao, J.; Li, J.; Hu, X.; Li, L. Long non-coding RNA emergence during renal cell carcinoma tumorigenesis. Cell Physiol. Biochem. 2018, 47, 735-746. [CrossRef] [PubMed]

113. Liu, X.; Xiao, Z.D.; Han, L.; Zhang, J.; Lee, S.W.; Wang, W.; Lee, H.; Zhuang, L.; Chen, J.; Lin, H.K.; et al. LncRNA NBR2 engages a metabolic checkpoint by regulating AMPK under energy stress. Nat. Cell Biol. 2016, 18, 431-442. [CrossRef] [PubMed]

114. Lin, A.; Li, C.; Xing, Z.; Hu, Q.; Liang, K.; Han, L.; Wang, C.; Hawke, D.H.; Wang, S.; Zhang, Y.; et al. The LINK-A lncRNA activates normoxic HIF1alpha signalling in triple-negative breast cancer. Nat. Cell Biol. 2016, 18, 213-224. [CrossRef]

115. Yuan, J.H.; Liu, X.N.; Wang, T.T.; Pan, W.; Tao, Q.F.; Zhou, W.P.; Wang, F.; Sun, S.H. The MBNL3 splicing factor promotes hepatocellular carcinoma by increasing PXN expression through the alternative splicing of lncRNA-PXN-AS1. Nat. Cell Biol. 2017, 19, 820-832. [CrossRef]

116. Zhu, X.T.; Yuan, J.H.; Zhu, T.T.; Li, Y.Y.; Cheng, X.Y. Long noncoding RNA glypican 3 (GPC3) antisense transcript 1 promotes hepatocellular carcinoma progression via epigenetically activating GPC3. FEBS J. 2016, 283, 3739-3754. [CrossRef]

117. Gibb, E.A.; Vucic, E.A.; Enfield, K.S.; Stewart, G.L.; Lonergan, K.M.; Kennett, J.Y.; Becker-Santos, D.D.; MacAulay, C.E.; Lam, S.; Brown, C.J.; et al. Human cancer long non-coding RNA transcriptomes. PLoS ONE 2011, 6, e25915. [CrossRef] [PubMed]

118. Zhang, B.; Chu, W.; Wen, F.; Zhang, L.; Sun, L.; Hu, B.; Wang, J.; Su, Q.; Mei, Y.; Cao, J.; et al. Dysregulation of Long Non-coding RNAs and mRNAs in Plasma of Clear Cell Renal Cell Carcinoma Patients Using Microarray and Bioinformatic Analysis. Front. Oncol. 2020, 10, 559730. [CrossRef] 
119. Wu, Y.; Wang, Y.Q.; Weng, W.W.; Zhang, Q.Y.; Yang, X.Q.; Gan, H.L.; Yang, Y.S.; Zhang, P.P.; Sun, M.H.; Xu, M.D.; et al. A serum-circulating long noncoding RNA signature can discriminate between patients with clear cell renal cell carcinoma and healthy controls. Oncogenesis 2016, 5, e192. [CrossRef]

120. Kogure, T.; Yan, I.K.; Lin, W.L.; Patel, T. Extracellular vesicle-mediated transfer of a novel long noncoding RNA TUC339: A mechanism of intercellular signaling in human hepatocellular cancer. Genes. Cancer 2013, 4, 261-272. [CrossRef]

121. He, Z.H.; Qin, X.H.; Zhang, X.L.; Yi, J.W.; Han, J.Y. Long noncoding RNA GIHCG is a potential diagnostic and prognostic biomarker and therapeutic target for renal cell carcinoma. Eur. Rev. Med. Pharmacol. Sci. 2018, 22, 46-54.

122. Xie, J.; Zhong, Y.; Chen, R.; Li, G.; Luo, Y.; Yang, J.; Sun, Z.; Liu, Y.; Liu, P.; Wang, N.; et al. Serum long non-coding RNA LINC00887 as a potential biomarker for diagnosis of renal cell carcinoma. FEBS Open Biol. 2020, 10, 1802-1809. [CrossRef]

123. McAnena, P.; Brown, J.A.; Kerin, M.J. Circulating Nucleosomes and Nucleosome Modifications as Biomarkers in Cancer. Cancers 2017, 9, 5. [CrossRef]

124. Sole, C.; Arnaiz, E.; Manterola, L.; Otaegui, D.; Lawrie, C.H. The circulating transcriptome as a source of cancer liquid biopsy biomarkers. Semin. Cancer Biol. 2019, 58, 100-108. [CrossRef]

125. Dietrich, D.; Meller, S.; Uhl, B.; Ralla, B.; Stephan, C.; Jung, K.; Ellinger, J.; Kristiansen, G. Nucleic acid-based tissue biomarkers of urologic malignancies. Crit. Rev. Clin. Lab. Sci. 2014, 51, 173-199. [CrossRef] [PubMed]

126. Guo, M.; Wu, Y. Fighting an old war with a new weapon silencing transposons by Piwi-interacting RNA. IUBMB Life 2013, 65, 739-747. [CrossRef] [PubMed]

127. Busch, J.; Ralla, B.; Jung, M.; Wotschofsky, Z.; Trujillo-Arribas, E.; Schwabe, P.; Kilic, E.; Fendler, A.; Jung, K. Piwi-interacting RNAs as novel prognostic markers in clear cell renal cell carcinomas. J. Exp. Clin. Cancer Res. 2015, 34, 61. [CrossRef]

128. Li, Y.; Wu, X.; Gao, H.; Jin, J.M.; Li, A.X.; Kim, Y.S.; Pal, S.K.; Nelson, R.A.; Lau, C.M.; Guo, C.; et al. Piwi-Interacting RNAs (piRNAs) Are Dysregulated in Renal Cell Carcinoma and Associated with Tumor Metastasis and Cancer-Specific Survival. Mol. Med. 2015, 21, 381-388. [CrossRef] [PubMed]

129. Iliev, R.; Fedorko, M.; Machackova, T.; Mlcochova, H.; Svoboda, M.; Pacik, D.; Dolezel, J.; Stanik, M.; Slaby, O. Expression Levels of PIWI-interacting RNA, piR-823, Are Deregulated in Tumor Tissue, Blood Serum and Urine of Patients with Renal Cell Carcinoma. Anticancer Res. 2016, 36, 6419-6423. [CrossRef]

130. Zhao, C.; Tolkach, Y.; Schmidt, D.; Toma, M.; Muders, M.H.; Kristiansen, G.; Müller, S.C.; Ellinger, J. Mitochondrial PIWIinteracting RNAs are novel biomarkers for clear cell renal cell carcinoma. World J. Urol. 2019, 37, 1639-1647. [CrossRef] [PubMed]

131. Zhao, Z.; Shilatifard, A. Epigenetic modifications of histones in cancer. Genome Biol. 2019, 20, 245. [CrossRef] [PubMed]

132. Bauden, M.; Pamart, D.; Ansari, D.; Herzog, M.; Eccleston, M.; Micallef, J.; Andersson, B.; Andersson, R. Circulating nucleosomes as epigenetic biomarkers in pancreatic cancer. Clin. Epigenet. 2015, 7, 106. [CrossRef] [PubMed]

133. Rasmussen, L.; Christensen, I.J.; Herzog, M.; Micallef, J.; Nielsen, H.J. Danish Collaborative Group on Early Detection of Colorectal Cancer. Circulating cell-free nucleosomes as biomarkers for early detection of colorectal cancer. Oncotarget 2017, 9, 10247-10258. [CrossRef] [PubMed] 